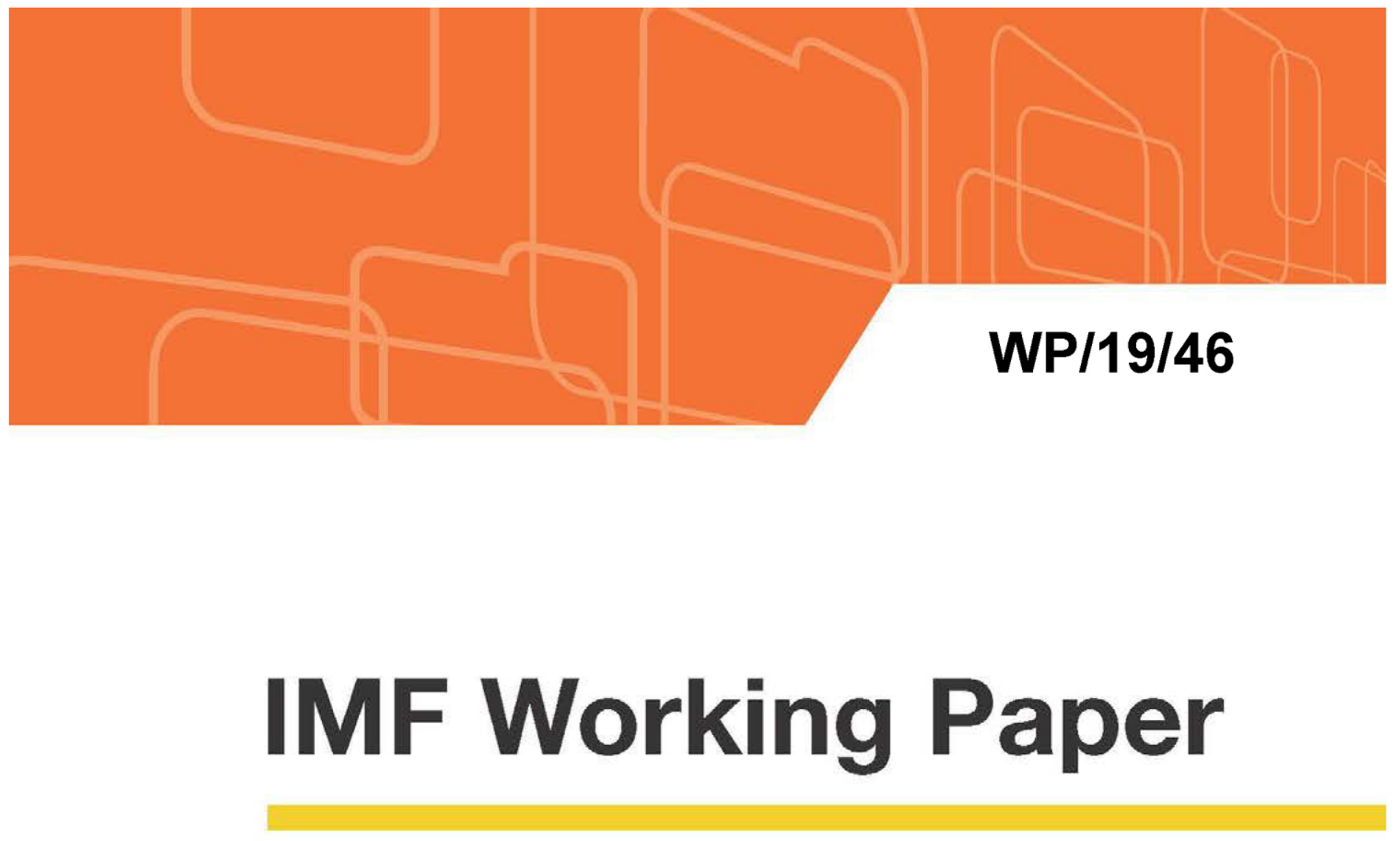

\title{
Cash Use Across Countries and the Demand for Central Bank Digital Currency
}

by Tanai Khiaonarong and David Humphrey

IMF Working Papers describe research in progress by the author(s) and are published to elicit comments and to encourage debate. The views expressed in IMF Working Papers are those of the author(s) and do not necessarily represent the views of the IMF, its Executive Board, or IMF management. 


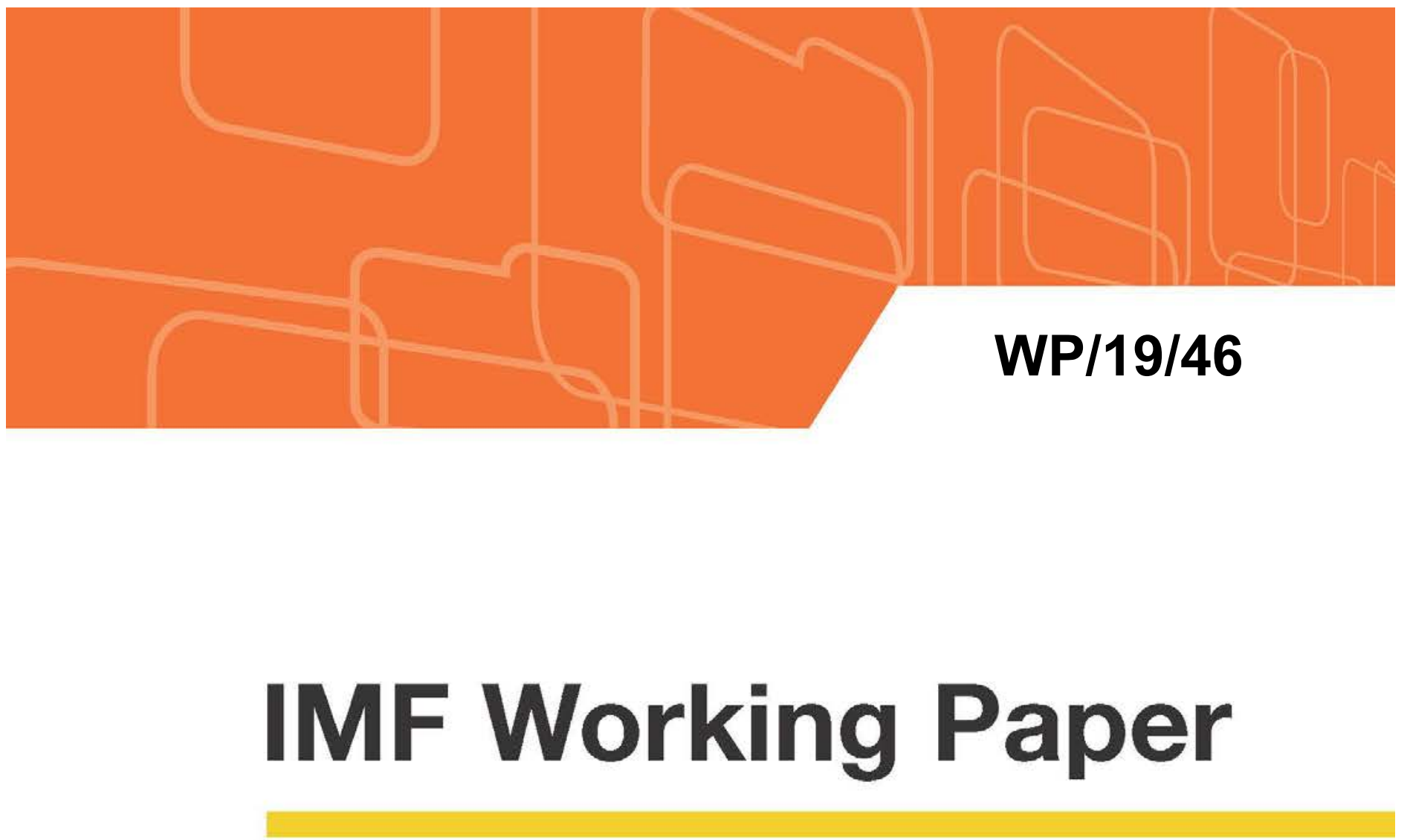

\section{Cash Use Across Countries and the Demand for Central Bank Digital Currency}

by Tanai Khiaonarong and David Humphrey

IMF Working Papers describe research in progress by the author(s) and are published to elicit comments and to encourage debate. The views expressed in IMF Working Papers are those of the author(s) and do not necessarily represent the views of the IMF, its Executive Board, or IMF management.

$$
\text { I N T E R N A T I O N A L M O N E T A R Y F U N D }
$$




\title{
IMF Working Paper
}

Monetary and Capital Markets Department

\section{Cash Use Across Countries and the Demand for Central Bank Digital Currency Prepared by Tanai Khiaonarong and David Humphrey}

Authorized for distribution by Jihad Alwazir

March 2019

\begin{abstract}
IMF Working Papers describe research in progress by the author(s) and are published to elicit comments and to encourage debate. The views expressed in IMF Working Papers are those of the author(s) and do not necessarily represent the views of the IMF, its Executive Board, or IMF management.
\end{abstract}

\begin{abstract}
The level and trend in cash use in a country will influence the demand for central bank digital currency (CBDC). While access to digital currency will be more convenient than traveling to an ATM, it only makes CBDC like a bank debit card - not better. Demand for digital currency will thus be weak in countries where cash use is already very low, due to a preference for cash substitutes (cards, electronic money, mobile phone payments). Where cash use is very high, demand should be stronger, due to a lack of cash substitutes. As the demand for CBDC is tied to the current level of cash use, we estimate the level and trend in cash use for 11 countries using four different measures. A tentative forecast of cash use is also made. After showing that declining cash use is largely associated with demographic change, we tie the level of cash use to the likely demand for CBDC in different countries. In this process, we suggest that one measure of cash use is more useful than the others. If cash is important for monetary policy, payment instrument competition, or as an alternative payment instrument in the event of operational problems with privately supplied payment methods, the introduction of CBDC may best be introduced before cash substitutes become so ubiquitous that the viability of CBDC could be in doubt.
\end{abstract}

\section{JEL Classification Numbers: E41 E42 E58 E59}

Keywords: cash use, cash forecasting, central bank digital currency

Authors’ E-Mail Addresses: tkhiaonarong@,imf.org; dhumphrey@cob.fsu.edu

We are grateful for input and comments from Itai Agur, Jana Bricco, Mu Changchun, Fei Han, Kotaro Ishi, Nicole Jonker, Marianne Koch, Klaus Löber, Aiko Mineshima, Harish Natarajan, Mia Qiu, Knut Sandal, Björn Segendorf, Froukelien Wendt, and seminar participants at the IMF. Karen Lee provided research assistance. Wifianni Wirsatyo and Danica Owczar provided editorial assistance. 


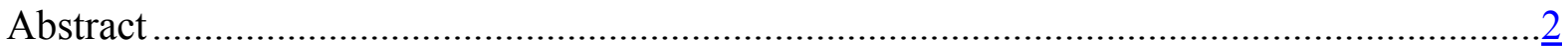

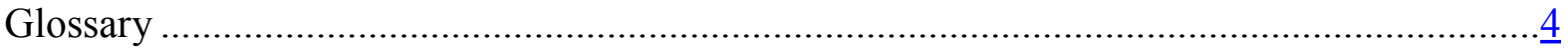

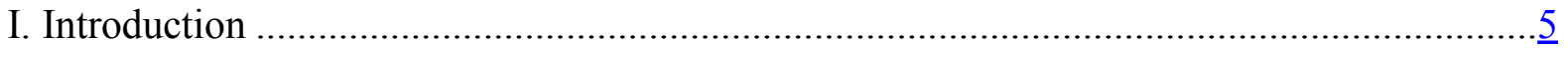

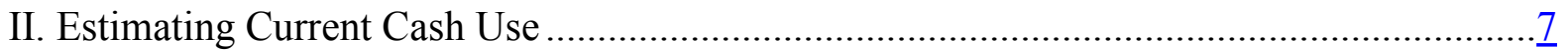

A. Currency in Circulation to GDP..............................................................

B. Household Consumption Minus Cash Payment Substitutes ...............................10

C. Share of Cash Withdrawals in Household Consumption ...................................... 11

D. Share of Cash Withdrawals in Total Cash and Cash-Like Payments .....................12

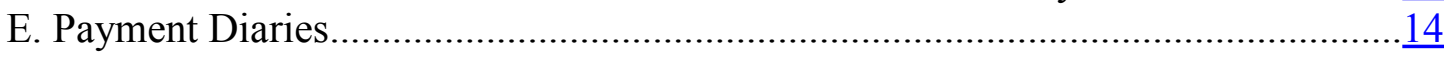

III. Forecasting Cash Use................................................................................. 15

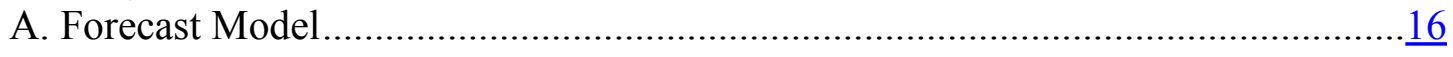

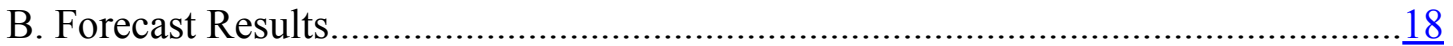

IV. Past Changes in Payment Use.........................................................................

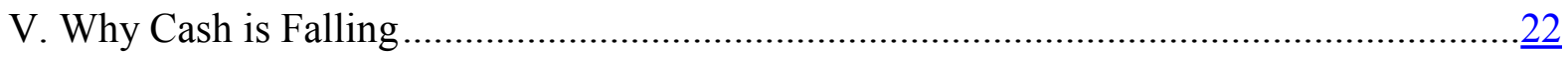

VI. Benefits and Costs of Central Bank Digital Currency .................................................24

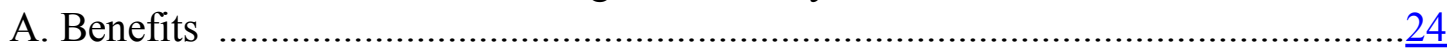

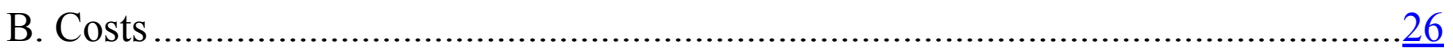

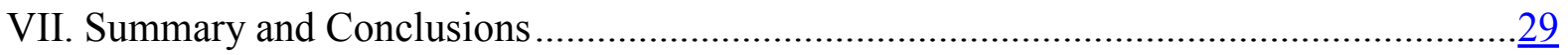

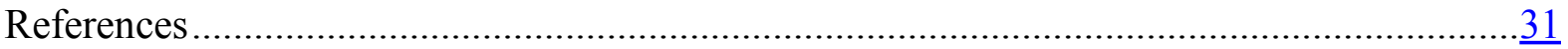

Tables

1. Reductions in Cash Use Over 2006-16 ................................................................ 14

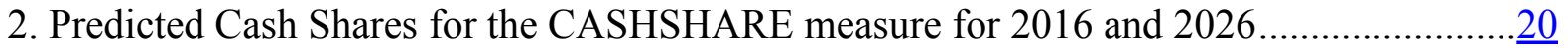

Figures

1. Currency in Circulation to GDP, 2006-16 .................................................................. $q$

2. Share of Cash in Cash, Card, and E-Money Transaction Value, 2006-16 .......................12

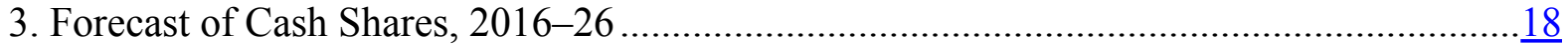

Boxes

1. Payment Diary Studies.....................................................................................

2. Central Bank Digital Currency Studies in Selected Countries ........................................28

Appendixes

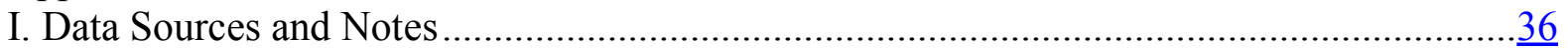

II. Cash Use Indicators in Eleven Countries, 2006-2016 ….......................................... 38 


\section{GLOSSARY}

$\begin{array}{ll}\text { ACH } & \text { Automated Clearing House } \\ \text { ATM } & \text { Automated Teller Machine } \\ \text { BIS } & \text { Bank for International Settlements } \\ \text { CBDC } & \text { Central Bank Digital Currency } \\ \text { CIC } & \text { Currency in Circulation } \\ \text { CPMI } & \text { Committee on Payments and Market Infrastructures } \\ \text { ECB } & \text { European Central Bank } \\ \text { GDP } & \text { Gross Domestic Product } \\ \text { OECD } & \text { Organization for Economic Co-operation and Development } \\ \text { OTC } & \text { Over the Counter } \\ \text { POS } & \text { Point of Sale } \\ \text { U.K. } & \text { United Kingdom } \\ \text { U.S. } & \text { United States }\end{array}$




\section{INTRODUCTION}

Central banks issue and maintain a country's currency. In many developed countries, currency use is falling and, in a few, the current use of currency is already low. One example is Sweden. The share of cash payments in retail transactions fell from 40 percent to only 15 percent between 2010 and 2016. Two-thirds of Swedish consumers say they can get by without cash (Sveriges Riksbank, 2017). Cards, e-money, and Swish (a mobile phone payment system) are used instead.

As a response, some central banks are investigating the possibility of issuing digital currency as a future replacement for cash. The alternative is to accept the possibility that over time physical cash may be almost wholly replaced by substitute payment instruments tied to private bank deposit money. A pilot program is being considered in one country to determine how central bank digital currency (CBDC) may operate if adopted. ${ }^{1}$ To see how fast cash use may be falling, we estimate the use of physical currency in 11 countries over 2006-16 and forecast how this use may change over the next 5 to 10 years. Estimates of current cash use are from simple indirect and direct calculations fitted with a cubic spline. Logistic curves are used to obtain cash share forecasts going forward.

To date, the discussion regarding digital cash has chiefly centered on supply side concernsthe benefits of digital cash, why it may be needed, and possible ramifications if adopted. We focus on the demand for digital cash. Demand will depend on the cost and convenience of CBDC for potential users relative to payment instruments that have already replaced some or many cash transactions. Historically, prior to the development of bank cards, in some countries checks replaced cash at the point of sale (POS), for bill payments, and employee disbursements, while in other countries giro transactions played a similar cash replacement role. Cards are a more recent development and have continued the process of cash replacement, as has the use of e-money with value stored in mobile phones or reloadable cards. Mobile phone payments and instant Internet payments in some countries are doing the same.

Without the benefit of significantly lower cost and/or improved convenience over currently used substitutes for cash, the effort to replace physical cash with digital cash may, as an upper limit, only replace the current level of cash use in a country. It is likely to be less than this. Cash, in either physical or digital form, lacking a competitive edge relative to current cash substitutes, could continue to decline to such a low level that the benefits some central banks attribute to cash are not realized. As a result, older adults who typically use more cash for their transactions than younger adults, and are not comfortable with electronic payment

\footnotetext{
${ }^{1}$ In what follows, central bank digital currency is also referred to as CBDC or simply digital cash while cash represents physical cash or currency already in use.
} 
methods, could be disadvantaged if cash is no longer generally accepted at stores and banks attempt to save cost by limiting access to cash as its usage falls to de minimis levels.

Popular payment instruments such as cards, mobile phone payments, and instant payments all have first-mover advantage. Current cash substitutes may be too dominant and entrenched, especially if cash use falls to very low levels. If cash is important for monetary policy, payment instrument competition, or as an alternative (and risk free) payment instrument in the event of operational problems with privately supplied payment methods, the introduction of CBDC may best be introduced before cash substitutes become so ubiquitous that the viability of digital cash could be in doubt.

Relying on multiple data sources, the current use of cash for 11 countries over 2006 to 2016 is illustrated in Section II. This covers Australia, China, Denmark, Germany, India, Japan, Netherlands, Norway, Singapore, United Kingdom (U.K.), and United States (U.S.). ${ }^{2}$ Four ways of illustrating cash use are shown and compared across countries. All four measures have deficiencies. The most common method currently used is found to be misleading and is rejected. The remaining three measures suggest that the average cash share across countries falls by 1.3 to 2.2 percentage points (hereafter, pp) per year.

Section III presents the results of forecasting cash use over the next 5 to 10 years. While one would perhaps expect to see a reverse Gompertz S-curve, for almost all countries the time period covered is too short for this to be strongly evident. The usual result is simply a slightly curvilinear downward trend with average cash forecasted to fall by 1.4 percentage points a year over 2016-2016.

The experience of earlier important changes in payment instrument use are briefly outlined in Sections IV and V. These changes improved convenience and lowered user, receiver, and/or supplier costs. Surveys show that younger adults favor non-cash payment methods (cards, mobile phones) over cash, while the reverse applies for older adults. Thus, natural demographic change is sufficient to explain declining cash use. As the former cohort replaces the latter one, this progression will be hard to stop or reverse.

The costs and benefits of CBDC outlined in central bank publications mostly deal with supply-side considerations and the possible need to maintain a role for cash in an economy. These are critically examined in Section VI. While access to CBDC will be more convenient than access to physical cash, this only makes CBDC the same as a bank debit card—not

\footnotetext{
2 The selection of countries was based only on data availability. As data are developed or found, the analysis could be extended to other countries.
} 
better. Without other incentives, the demand for digital cash will be weak. Our results are summarized in Section VII.

\section{Estimating Current Cash Use}

What is the best way to measure cash use in a country? If one knows the value of cash expenditures, cash use can be measured on a per person basis or as ratio to GDP, household consumption, or cash expenditures plus the value of other payment instruments that commonly substitute for cash (i.e., the market for cash). The trend or change in cash use can be determined with any or all of these four measures. Even though the numerator (the value of cash expenditures) may be the same, the level of cash use will differ as there would be four different numeraires. The denominator could be population, GDP, household consumption, or the value of cash expenditures plus non-cash instruments that commonly compete with cash in transactions. Only the latter numeraire indicates why cash use may be rising or falling. All the others are silent. While we believe this measure is best-it contains the most information —we illustrate three other measures for comparison. ${ }^{3}$

Our first method for estimating cash use across countries is the most popular. It uses a ratio of a country's currency in circulation to GDP. A second measure takes the value of household consumption and subtracts the value of all non-cash payment instruments used in consumption and estimates cash use as the residual. A third is the value of cash withdrawn from automated teller machines (ATMs) and over the counter at banks as a ratio to household consumption. A final method, which is our preferred measure, uses the value of all cash withdrawals as a ratio to cash plus the value of payment instruments that substitute for cash (cards plus e-money). This reflects the market for cash. Point estimates of cash use from payment diaries, kept by relatively small samples of consumers in a country, are also presented. ${ }^{4}$ We note that the cash withdrawal information used in two of our measures is equivalent to a time-series of a national level diary of cash use.

All the information needed to show how cash use varies over time is contained in a simple equation: $\mathrm{S}_{\mathrm{t}}=\alpha+\beta \mathrm{t}$. $\mathrm{S}_{\mathrm{t}}$ is the share of cash payments in a country (however measured), $\alpha$ is an intercept, $\beta$ is a slope, while $t$ is time as in $(2006,2007, \ldots, 2016)$. All variables that

\footnotetext{
${ }^{3}$ A more common comparison may help. Consider measuring beef consumption in a country: the value of beef consumed to GDP, to population, or to the market for meat. All three can be used to see the trend in beef consumption. However, the measured level of beef consumption will differ-low relative to GDP but high relative to the (smaller) market for meat. Also, beef consumption to GDP will not be a good comparison across countries since GDP can vary independently from the demand for beef. Beef consumption per person is better. While culture and tastes differ across countries, it does not change much over time. However, only when considering the market for meat — not just beef-will it be obvious why beef consumption may be changing. Here the measure is: (beef consumption)/(beef + chicken + pork + lamb + etc.) which has more information regarding beef consumption. It shows what is substituting for beef or vice versa.

${ }^{4}$ Time-series information from consumer payment diaries exists but is too limited to discern a trend for more than one or two of the countries we cover.
} 
influence the level of cash use will be reflected in $\alpha$ (the intercept). This could include a country's acceptance of technical change (reflecting culture), the development of and trust in the banking system, and past availability of newer electronic payment methods. Although interesting, there is no need to know why $\alpha$ is high for Germany but low for Norway. Everything that affects the level of cash use is already reflected in $\alpha$, although it remains unidentified. The same is true for $\beta$ (the slope). This reflects all the variables that affect the change in cash use, such as how fast or slow newer or more convenient or lower cost payment instruments are replacing cash in a country. In any case, our data set is too small to be able to well identify the underlying factors that influence the intercept - the level of cash use. We make an attempt to identify an important determinant of the slope-why cash use is falling.

\section{A. Currency in Circulation to GDP}

The most common way to express cash use in a country is to compute the ratio of currency in circulation (CIC) to nominal GDP. This is shown for 11 countries in the figures below. All figures use data in billions of purchasing power parity adjusted U.S. dollars. Appendix I contains information on the data used in all figures. Figure 1A shows the CIC/GDP ratio for 5 countries in Asia, while Figure 1B shows the ratio for 6 countries in Europe and the U.S. All computed cash use data are annual observations fitted using a cubic spline. ${ }^{5}$ Only in 3 of the 11 countries is cash use falling: India, China, and Norway. The other eight countries either show increasing cash use (Japan, Singapore, Germany, Netherlands, U.S., and U.K.) or approximately no change (Australia and Denmark). This basically replicates a more comprehensive analysis applying the ratio of CIC to GDP to a larger set of countries (Bech, et al., 2018).

The assumption underlying the CIC/GDP ratio is that currency in circulation should roughly reflect cash use in a country. This is not unreasonable but has to meet certain conditions to be comparable across countries. ${ }^{6}$ In addition, only the consumption component of GDP, and even then only the lower-valued consumption goods and services that are commonly purchased with cash and cash substitutes, should be in the denominator as this is where cash is used - again the market for cash. For this reason, the ratio of CIC to GDP is rejected. It is often used because data on CIC and GDP are easily available.

\footnotetext{
${ }^{5}$ A cubic spline is constructed from piecewise third-order polynomials and thus is quite flexible. It is just a way of smoothing the data, similar to a moving average. For many countries, not much smoothing is needed. Often, using a ruler to "fit" the observations would adequately illustrate the trend in cash use over 2006-16.

${ }^{6}$ We view the value of all cash withdrawn from ATMs and over the counter at banks (call this W) as currently being the most accurate indicator of cash use in a country. For CIC to be a similarly good indicator of cash use across countries, the ratio $\mathrm{W} / \mathrm{CIC}$ should be the same or quite similar across countries. This is possible only if the turnover rate of cash in transactions and the proportion of cash held idle at banks or central banks are the same across countries.
} 
Figure 1. Currency in Circulation to GDP, 2006-16

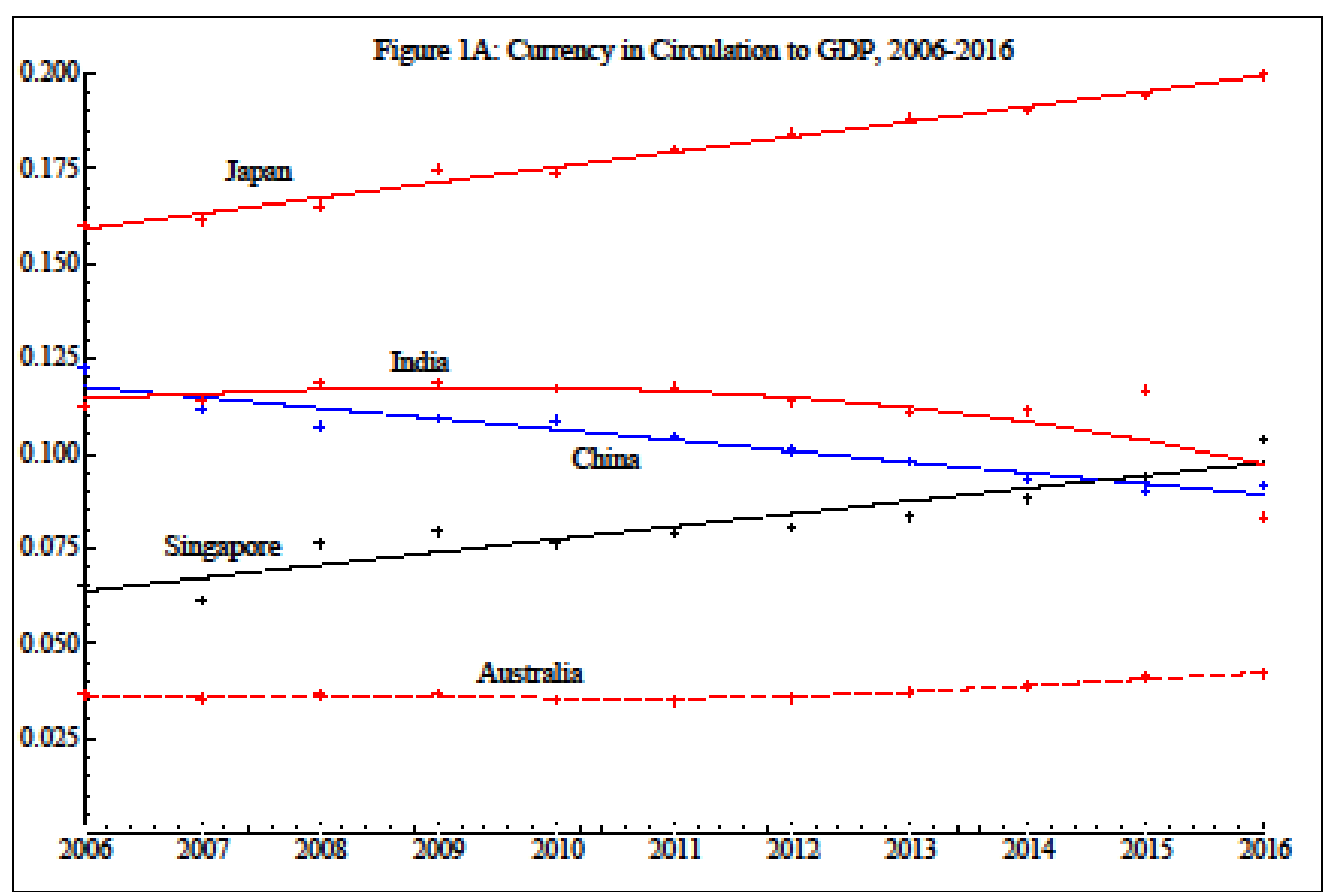

Sources: BIS, IMF and author's calculations.

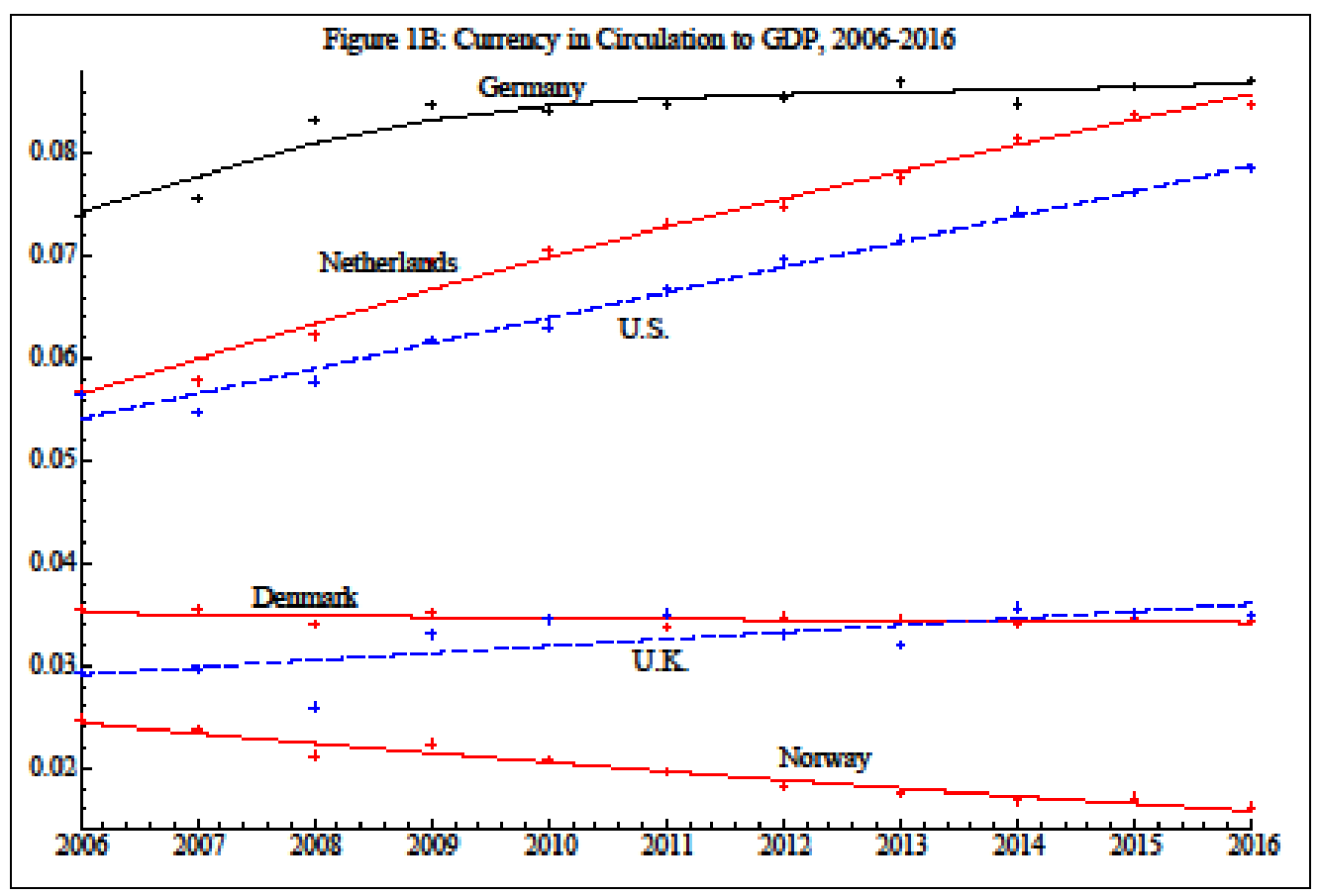

Sources: BIS, IMF and author's calculations.

This measure could be more useful if, instead of GDP, the denominator reflected only the value of consumption goods that cash is commonly used to purchase, but this information is more difficult to obtain. Fortunately, there is more information on payment instruments that 
substitute for cash than on cash itself. This leads to the following alternative measure of cash use in a country.

\section{B. Household Consumption Minus Cash Payment Substitutes}

If there is insufficient information on cash use in a country, it is possible to approximate it by selecting the components of GDP where cash is commonly used in transactions (such as the value of household consumption) and subtract the value of all non-cash payment instruments used in consumption. This gives the value of cash used as a residual. This measure is defined as $\mathrm{RESIDUALHC}=(\mathrm{HC}-\mathrm{CARD}-\mathrm{E}-\mathrm{MONEY}) / \mathrm{HC}$, where $\mathrm{HC}$ is the value of household consumption in the national accounts, CARD is the value of all debit and credit card payments, and E-MONEY is the value of private stored value cards or mobile phones with value stored on a chip. E-money is a pre-paid bearer payment instrument or a mobile phone used to make an instant payment (if included in the reported data).

While this gives an estimate of cash use in consumption as a residual, it will be an overestimate. Cash use will be overstated because the value of consumption purchases made using checks, $\mathrm{ACH} /$ giro payments, or instant payments is not also subtracted in the numerator. This is composed of two parts: the value of these consumption purchases that compete with cards and e-money (which is small and denoted as X1) and the value of these consumption purchases that are not considered cash substitutes (which is large and denoted as X2). The goal is to subtract all non-cash payments for consumption goods and services whether or not they substitute for cash. Thus, the proper computation would be: (HC $\mathrm{CARD}-\mathrm{E}-\mathrm{money}-\mathrm{X} 1-\mathrm{X} 2) / \mathrm{HC}$, but the $\mathrm{X}$ values are unknown and likely differ across countries. $^{7}$

The 11 figures shown in Appendix II illustrate the residual measure for each country (along with two additional measures discussed next). The residual approach suggests that cash use has fallen over time, at times quite significantly. ${ }^{8}$ In 2016, the highest share of cash use in household consumption was 84 percent for Germany ( 82 percent for Japan), while the lowest was 31 percent for the U.K. (with 39 percent for Norway). The average percentage point (pp) reduction in the computed shares shown for 10 countries in Appendix 2 was $13.3 \mathrm{pp}$, or 1.3 pp per year over 10 years.

\footnotetext{
${ }^{7}$ Information exists on X1 + X2 only as a sum and then only for all components of GDP as a total. It is not broken out for consumption alone nor additionally separated into consumption items where cash is commonly used for payment (X1) or consumption items where cash is not a competitive payment instrument (X2). With central bank assistance, and access to detailed data on household consumption, it was possible to properly compute the residual approach in an earlier study of cash use in Norway (Humphrey, Kaloudis, and Owre, 2004).

${ }^{8}$ The exception is China where there clearly is a problem with the data or the application of the residual approach to this country. The reduction in cash use is over 100 percent (which is impossible). Values in the text for this measure exclude China.
} 
The residual approach overestimates the level of cash use, which overstates the intercept for each country. The fact that the year-to-year variation in the slope is small suggests that the problem affecting the intercept does not have much effect on the slope. That is, the average cross-country variation in the slope of $1.3 \mathrm{pp}$ a year is a combination of the actual reduction in cash use plus the mismeasurement of cash in the numerator. We just don't know which is which. Comparing the estimated annual reductions in cash use across this and two additional measures will help in making this determination.

\section{Share of Cash Withdrawals in Household Consumption}

The residual measure attempts to identify cash use by relying on the value of non-cash payment instruments used to purchase those consumption goods which may or may not commonly compete with purchases made with cash. A more direct method would be to determine the value of total sales of consumption goods commonly made with cash. If it is assumed that cash withdrawn from ATMs and over the counter (OTC) at banks in a country is almost all spent on household consumption items, this value can be related to the value of household consumption in: $\mathrm{CASHHC}=(\mathrm{ATM}+\mathrm{OTC}$ cash $) / \mathrm{HC}$. This corrects the mismeasurement of the numerator in the residual approach but, as cash withdrawals do not include cash-back at the POS, the numerator is still to a degree mismeasured.

The value of cash withdrawn from ATMs and banks is similar to the value of cash used from a national level payment diary for all consumers. ${ }^{9}$ This measure is shown for each country in Appendix II. The results for China and India show a rise in cash use while the other nine countries show a reduction. The highest share of cash use in 2016 was 36 percent for Germany ( 24 percent for Singapore), and the lowest was 6 percent for Japan (with 7 percent for Norway).

These shares are lower than those of the residual method indicating the level of intercept overstatement with the residual method. The average reduction in cash use across the countries (excluding China and India) was 1.4 pp per year, which is very close to the annual 1.3 percentage point reduction found for the residual method. This suggests that the intercept measurement bias of the residual method has little effect on the slope.

Many would be satisfied with this measure of cash use; namely, the value of cash as a percent of total household consumption. But cash is not commonly spent on all consumption items. If we want to focus on the "market" for cash purchases, the denominator should only include consumption goods purchased with cash and current direct substitutes for cash (cards, e-money) plus the value of check, $\mathrm{ACH}$, giro, and instant payments that substitute for

\footnotetext{
${ }^{9}$ The cash withdrawal data was obtained with data assistance from certain central banks and from the publication Global Cash Index by Payments.com. Unfortunately, no information exists on the value of cash withdrawn that is held idle for hoarding or precautionary purposes rather than spent on consumption. Even so, the year-to-year variation here should normally be rather small so the slope should not be much affected.
} 
cash in consumption (X1). If so, this calculation is: (ATM + OTC cash)/HC - X2), which reduces the denominator. ${ }^{10}$ If one prefers to focus on the market for cash purchases, as we do, the current measure here that includes all consumption in the denominator will understate the level of cash use. The next measure makes this adjustment to the denominator.

\section{Share of Cash Withdrawals in Total Cash and Cash-Like Payments}

The share of cash used in the market for cash is the value of cash withdrawals as a percent of the value of transactions made using these withdrawals plus two of the currently strongest substitutes for cash: CASHSHARE $=($ ATM + OTC cash $) /($ ATM + OTC cash + CARD + EMONEY). The numerator is the same as the prior measure, but the denominator is smaller. Even here we face a problem of not having information on the value of check, ACH/Giro, and instant payments used to purchase consumption goods which commonly compete with cash (X1). The proper calculation would be (ATM + OTC cash)/(ATM + OTC cash + CARD $+\mathrm{E}-\mathrm{MONEY}+\mathrm{X} 1)$, although $\mathrm{X} 1$ is believed to be very small. This measure is shown in Figure 2 (as well as the 11 figures in Appendix II). All but India show a falling use of cash over the period. ${ }^{11}$

Figure 2. Share of Cash in Cash, Card, and E-Money Transaction Value, 2006-16

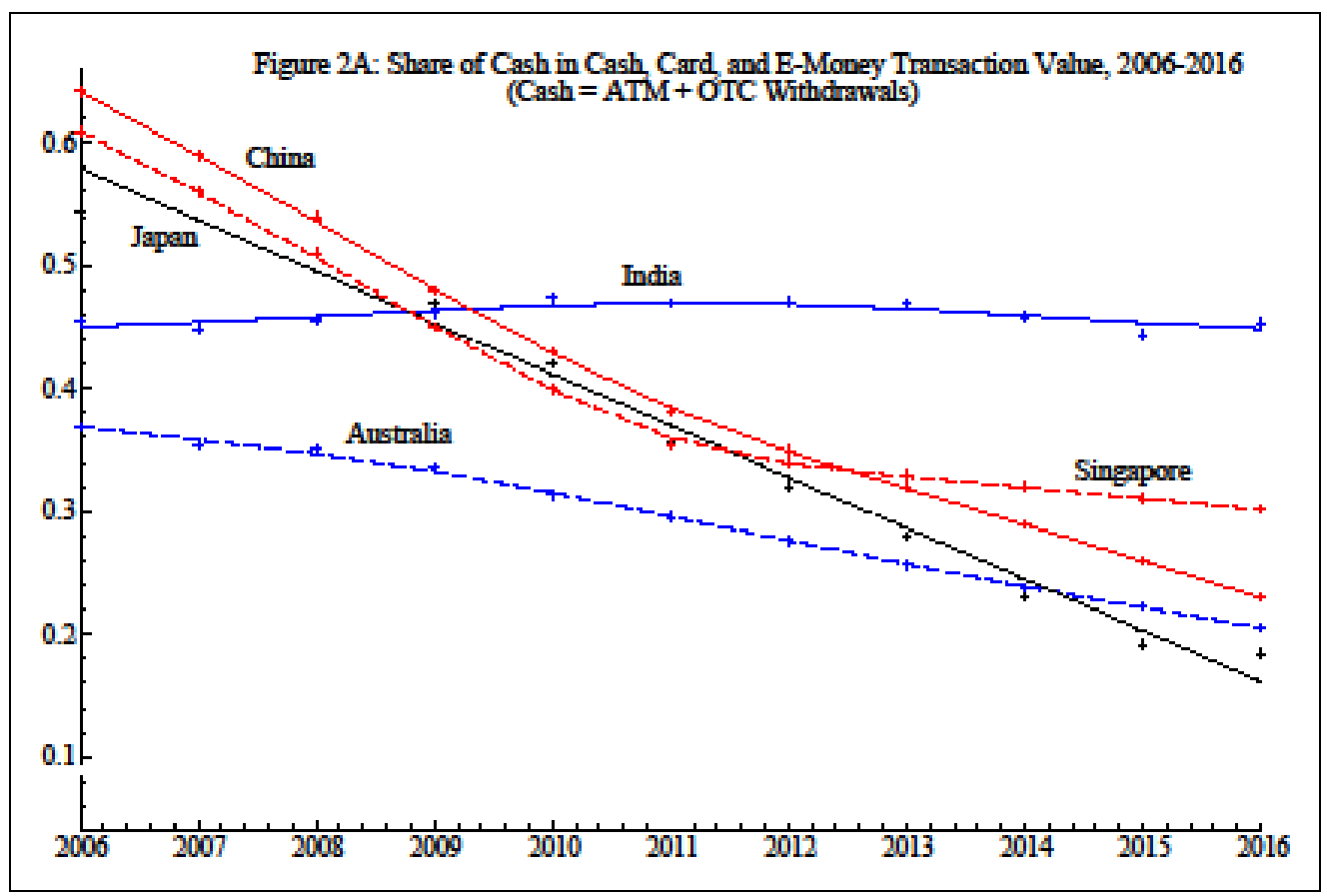

Sources: BIS, Payments.com, and author's calculations.

\footnotetext{
${ }^{10}$ Alternatively, this makes the denominator (ATM + OTC cash + CARDS + E-MONEY + X1). This is the desired denominator for the next cash use measure focusing on the market for cash. Hard evidence is lacking but anecdotal information suggests that X1 is very small in OECD countries.

${ }^{11}$ Data for India includes the disruption due to the 2016 demonetization exercise.
} 


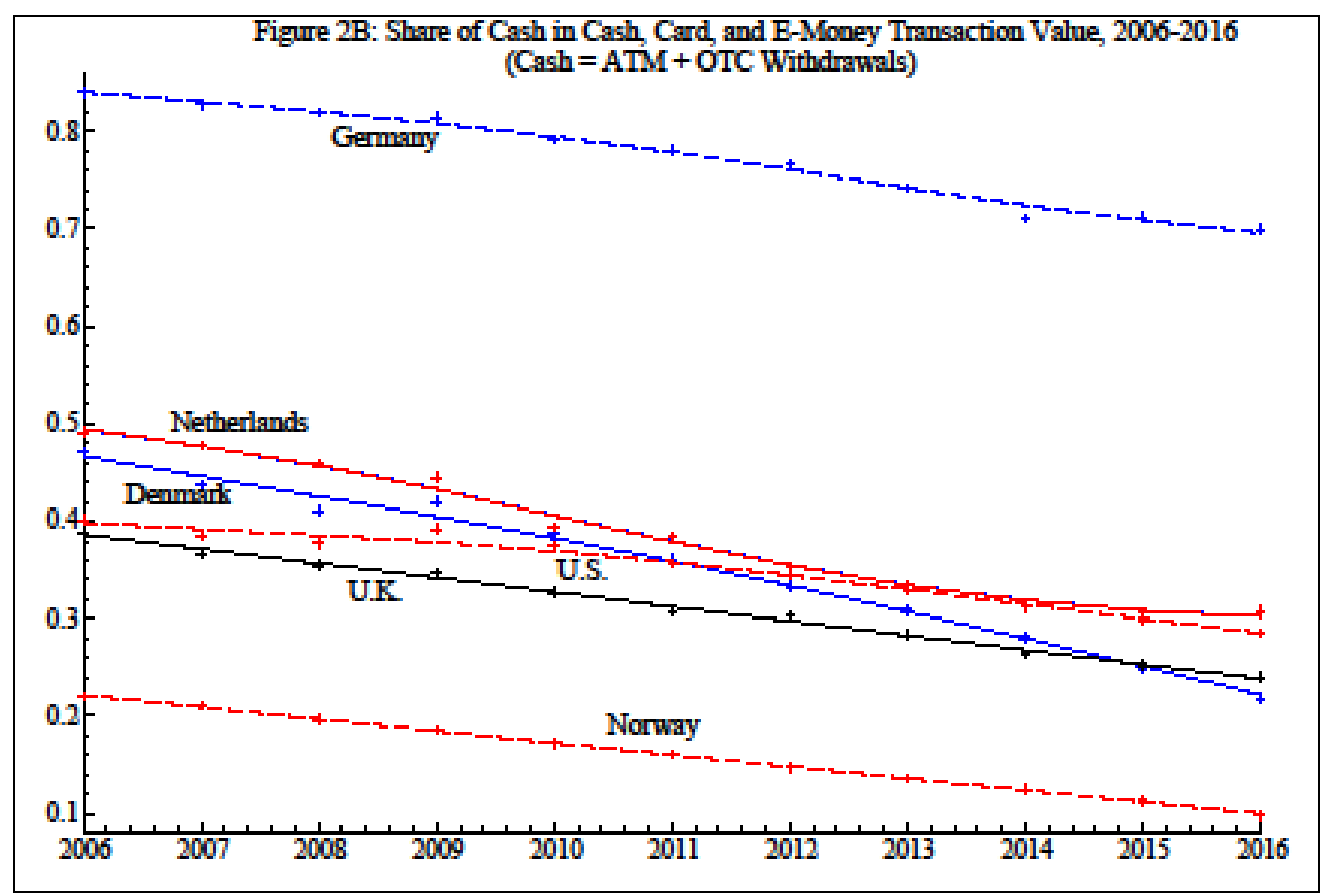

Sources: BIS, ECB, Danmarks Nationalbank, Norges Bank, Payments.com, and author's calculations.

To summarize the results, the intercepts - the cash share levels - are mismeasured, to differing degrees due to missing data. The smallest mismeasurement occurs for our preferred measure. Fortunately, this seems to have little effect on the estimated trend in cash use. The trend in cash use indicated by the slope (last row of Table 1) suggests that cash use across countries fell by an average of $1.3 \mathrm{pp}, 1.4 \mathrm{pp}$, and 2.2 pp per year, respectively, over 20062016 for the three measures we find most useful. Thus, the average reduction in cash use is quite similar, between 1.3 and 2.2 pp a year. ${ }^{12}$

This suggests that the driving force behind the reduction in cash use across countries is similar and, as noted below, may be related to demographic change. However, this does not mean that the percentage changes will be similar across countries as the bases for the percentage point changes - the levels of cash use across countries - can be quite different. A 1.4 pp yearly reduction in cash use for Germany using an average of the cash use levels observed in 2006 and 2016 of $77 \%$ (giving an annual average $1.8 \%$ change) is quite different from a similarly small $1.2 \mathrm{pp}$ change from an average base of 16 for Norway (giving a $7.5 \%$ annual change from a lower base).

\footnotetext{
${ }^{12}$ Numbers in the table have been rounded off. Impossible results (greater than a $100 \%$ reduction in cash use for China), negative values (rising cash use for China and India), and no net change in cash use (India) reflected in Table 1 for, respectively, each of the three measures shown, were excluded when the average changes in cash use were computed. Cash use results for these two countries seem to have problems that we have not resolved.
} 
Table 1. Reductions in Cash Use Over 2006-16

\begin{tabular}{|l|c|c|c|c|c|}
\hline & $\begin{array}{c}\text { RESIDUAL/HC } \\
\text { Annual Change } \\
\mathrm{pp}\end{array}$ & $\begin{array}{c}\text { CASH/HC } \\
\text { Annual Change } \\
\mathrm{pp}\end{array}$ & $\begin{array}{c}\text { CASHSHARE } \\
\text { Annual Change } \\
\mathrm{pp}\end{array}$ & $\begin{array}{c}\text { CASHSHARE } \\
\text { Level in (2006) } \\
\text { and in 2016 }\end{array}$ & $\begin{array}{c}\text { CASHSHARE } \\
\text { Annual Change } \\
\%\end{array}$ \\
\hline Australia & 1.2 & 1.1 & 1.6 & $(37) 21$ & 6 \\
\hline China & 17.1 & -1.6 & 3.6 & $(54) 18$ & 10 \\
\hline Denmark & 1.0 & 2.2 & 2.5 & $(47) 22$ & 7 \\
\hline Germany & 0.4 & 1.5 & 1.4 & $(84) 70$ & 2 \\
\hline India & 2.0 & -1.7 & 0.0 & $(45) 45$ & 0 \\
\hline Japan & 0.6 & 1.5 & 4.1 & $(64) 23$ & 9 \\
\hline Netherlands & 1.3 & 0.9 & 1.8 & $(49) 31$ & 5 \\
\hline Norway & 0.6 & 0.9 & 1.2 & $(22) 10$ & 8 \\
\hline Singapore & 1.5 & 4.0 & 3.1 & $(61) 30$ & 7 \\
\hline U.K. & 3.3 & 0.5 & 1.5 & $(39) 24$ & 5 \\
\hline U.S. & 1.4 & 0.3 & 1.1 & $(40) 29$ & 3 \\
\hline Average & $\mathbf{1 . 3}$ & $\mathbf{1 . 4}$ & $\mathbf{2 . 2}$ & $(\mathbf{4 9 )} \mathbf{2 9}$ & $\mathbf{6}$ \\
\hline
\end{tabular}

Source: Author's calculations.

For our preferred measure (CASHSHARE), the second to last column in Table 1 shows the level of cash use for 2006 (in parenthesis) and 2016. The highest level of cash use in 2016 was $70 \%$ for Germany (45\% for India) while the lowest was $10 \%$ for Norway (with $23 \%$ for Japan). We expect that many countries where payment systems are less well developed and cash substitutes are limited would have a greater level of cash use than many of the countries shown here.

The average percentage point changes for the CASHSHARE measure are shown in the third to last column in Table 1. Taking Australia as an example, the cash use reduction in percentage points averaged $1.6 \mathrm{pp}$ over 2006-2016. Expressing this change as a percent of the average base for Australia of $29 \%$ (computed from the second to last column in the table), the average percent reduction was $6 \%$ each year over this period. As seen in the last column, the percent reduction in cash use fell faster in China, Denmark, Japan, Norway, and Singapore, than in Australia (which is the same as the overall average). Cash use in Germany, Netherlands, U.K. and U.S. fell at a slower rate while for India it did not fall at all.

\section{E. Payment Diaries}

Box 1 shows some results for payment diaries carried out in different countries. Although these studies typically lack a time-series dimension, they provide some additional information on cash use. However, only for Australia is there a good correspondence between the payment diary results and the 2016 cash share for two of our time-series measures above, possibly because of differences in the numeraires being used. 
A comparison of payment diary results across countries is contained in Bagnall, et al. (2014). Diary information, when "blown up" to reflect the adult population of a country, could provide a point estimate of the national level of cash use as well as use of other payment instruments that do not commonly substitute for cash. ${ }^{13}$ While there is no national level survey of cash use, for the U.S. (other than the value of cash withdrawals from ATMs and at banks) there is national survey data on debit card use (Gerdes, et al., 2016). Unfortunately, the "blown up" diary information on debit card use for the U.S. (37 billion transactions) is much smaller than the national survey data (61 billion). Thus, care should be taken in relying on extrapolating consumer payment diary information to the national level. More work on this way of obtaining a national estimate of cash use should be encouraged.

\section{Forecasting Cash USe}

It is reasonable to expect that a plot of annual observations on cash use over time-if long enough - would look something like a reverse Gompertz S-curve. Cash use would fall initially, gather speed, reach an inflection point and then start to fall at a decreasing rate until cash use is very small. As this occurs, currency would be withdrawn from circulation (usually highest values first), and the average fixed costs to maintain currency fitness per 1,000 currency units would rise. As currency use declines and is returned to the central bank, it no longer generates seigniorage revenues. Explicit government borrowing, equal to the face value of the currency withdrawn, would occur. This suggests that central banks could minimize the budgetary effects of losing seigniorage by issuing digital cash earlier rather than later, when cash may fall to minimum levels.

\footnotetext{
${ }^{13}$ Using payment diary information, Greene and Schuh (2017) found that U.S. consumers made an average of 14 cash payments per month with an average value of US\$22. There are some 250 million adults in the U.S. A rough approximation for cash transactions for the nation as a whole could be 42 billion cash transactions worth US\$931 billion over a year. This is from: 14.1 cash transactions per month $\times 12$ months $\times 250$ million adults $=$ 42.3 billion cash transactions a year, then 42.3 billion $\mathrm{x}$ the average cash transaction value of US\$22= US\$930.6 billion as the total value.
} 


\section{Box 1. Payment Diary Studies}

Being relatively new, payment diary studies are typically only available for one or just a few years. Such studies have been completed or commissioned by central banks. Representative results for cash use in a country are shown below. Both volume and value shares are shown in the table.

\begin{tabular}{lccc} 
Country & Period & \multicolumn{2}{c}{ Share of Cash ( percent) } \\
& & Volume & Value \\
Australia & 2016 & 37 & 18 \\
Canada & 2013 & 44 & 23 \\
Denmark & 2017 & 23 & 16 \\
Germany & 2017 & 74 & 48 \\
Netherlands & 2016 & 45 & 27 \\
Norway & $2017-18$ & 11 & 5 \\
Sweden & 2018 & 13 & n.a \\
U.S. & $2017(2015)$ & 27 & $(9)$
\end{tabular}

Diary information reflects the use of cash relative to the value of cash, card, and e-money at the POS (as measured in CASHSHARE above), but also reflect the value of ACH/GIRO transactions for bill payments, along with checks (in some countries) at the POS and for bill payments. Not all of these payments would also commonly be paid using cash and thus do not substitute for cash. We would exclude them from the cash share computations shown here.

Sources: Greene and Stavins (2018); Danmarks Nationalbank (2017); Esselink and Hernández (2017); Flannigan and Staib, 2017);

Doyle et al., (2017); Fung et al., (2015); Henry et al., (2015); European Central Bank (2017); Deutsche Bundesbank (2018); De

Nederlandsche Bank and the Dutch Payments Association (2017); Greene et al., (2017).

Note: For U.S., data for share of cash values for 2017 is not available so survey results from 2015 is used. Share of cash value is not available for Sweden.

\section{A. Forecast Model}

What might cash use look like in our 11 countries 5 or 10 years from now? Although our forecast model is estimated using standard regression procedures, it is clear that the degrees of freedom are too low to inspire much confidence from a purely statistical standpoint. In fact, fitting a linear trend with a ruler to the curves in Figures 2A and 2B would give a rather similar forecast.

Logistic and Gompertz growth or S-curves have been used in a variety of situations to forecast the adoption and dispersion of new technologies in industry and consumption (e.g., the adoption of the telephone and TVs) and can be adapted to forecast the possible future use 
of cash. In a detailed empirical comparison, Meade and Islam (1995) have shown that the standard logistic and Gompertz S-curves outperform more complicated models. ${ }^{14}$

A standard Gompertz S-curve model would be $\ln \left(S_{t} /\left(1-S_{t}\right)\right)=a+b t+e_{t}$ where, for example, $S_{t}$ is the share of electronic payments in a country and $b$ is the coefficient of diffusion or the slope of the $\mathrm{S}$-curve. In this case, $\mathrm{S}_{\mathrm{t}}$ is expected to rise over time $(\mathrm{t})$ first slowly, then gathering speed with greater adoption of electronic payment alternatives. At some point it reaches an inflection point and instead of continuing to rise at an increasing rate, only rises at a decreasing rate until the market is saturated. ${ }^{15}$

It is expected that the S-curve for the use of cash over time will be the reverse of the adoption of retail electronic payments as one basically substitutes for the other. Since the share of cash is expected to fall, rather than rise, the dependent variable in the equation using $\mathrm{S}_{\mathrm{t}}$ in the electronic payment application is reversed. The dependent variable in the estimated logistic curve (1) has been altered to show a falling cash payment share $\left(\mathrm{S}_{t}\right)$ as a function of time over 2006-2016. The estimated parameters have the same interpretation:

$$
\ln \left(\left(1-\mathrm{S}_{\mathrm{t}}\right) / \mathrm{S}_{\mathrm{t}}\right)=\mathrm{a}+\mathrm{bt}+\mathrm{e}_{\mathrm{t}}
$$

After estimation, the predicted cash shares $\left(S^{\prime}{ }_{t}\right)$ are found from $\exp \left(a^{\prime}+b^{\prime} t\right)=\left(1-S_{t}{ }_{t}\right) / S^{\prime}{ }_{t}$, where $a^{\prime}$ and $b^{\prime}$ are the estimated parameters while t now varies over the forecast period 2016-2026. Thus $S^{\prime}{ }_{t}=1 /\left(\exp \left(a^{\prime}+b^{\prime} t\right)+1\right) .{ }^{16}$ The pattern of initial cash use is used (via symmetry around its inflection point) to predict the remaining pattern of replacement. ${ }^{17}$

\footnotetext{
14 This is largely because more complicated models have more parameters to estimate and the data available typically cannot support the increased complexity.

${ }^{15}$ Applied to the adoption of the telephone and black and white TVs in the U.S., the saturation point was close to 100 percent. For basic cable TV, it was only about 65 percent while for satellite TV it was little more than 25 percent. Saturation need not be 100 percent.

${ }^{16}$ A similar approach was used in Khiaonarong and Humphrey (2005).

${ }^{17}$ The non-linear, symmetric logistic curve and the Gompertz non-linear, asymmetric curves ask too much of our limited data, which has few degrees of freedom and no observed inflection points, to be reliably estimated here. Consequently, only the linear, symmetric logistic model in (1) is estimated.
} 


\section{E. Forecast Results}

Only the cash use measure CASHSHARE is forecasted here. ${ }^{18}$ It is our preferred measure since it focuses on the market for cash purchases in a country. The results are shown in Figures $3 \mathrm{~A}$ and $3 \mathrm{~B} .{ }^{19}$

Figure 3. Forecast of Cash Shares, 2016-26

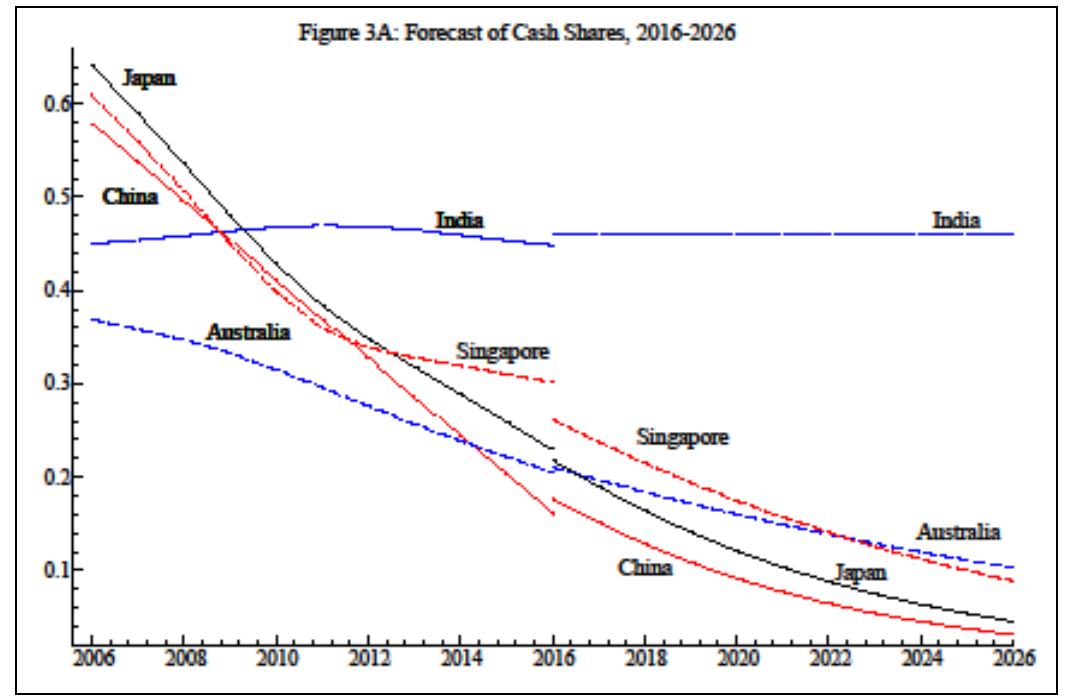

Sources: BIS, Payments.com, and author's calculations.

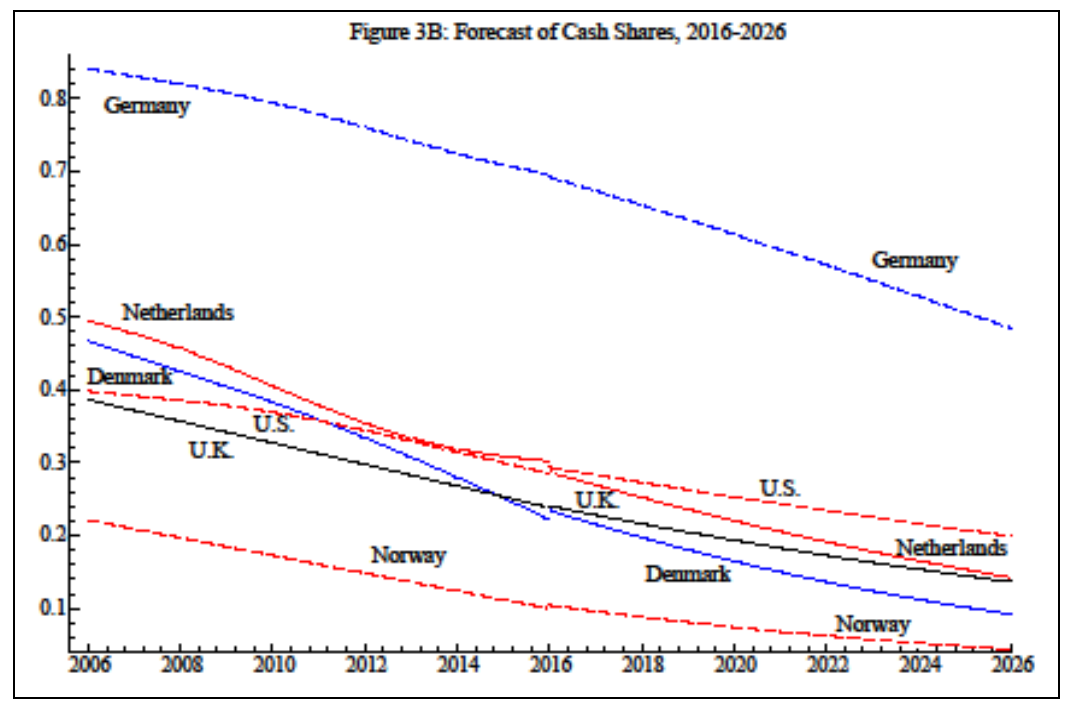

Sources: BIS, ECB, Danmarks Nationalbank, Norges Bank, Payments.com, and author's calculations.

${ }^{18} \mathrm{CASHSHARE}=\mathrm{S}_{\mathrm{t}}$ or $\mathrm{S}_{\mathrm{t}}{ }_{\mathrm{t}}=($ value of ATM + OTC cash withdrawals $) /($ value of ATM + OTC cash withdrawals + the values of card and e-money transactions).

${ }^{19}$ Plot marks in the figures were removed for clarity. 
The observed cash shares over 2006-16 are the same as shown in Figures 2A and 2B and were fitted using a cubic spline. The forecasting procedure, however, imposes a reverse Scurve functional form when estimated using data over 2006-2016. The results of that estimation were applied to the years 2016-26 to obtain predicted values. This explains why there is often a break in the slope of the curves in 2016. The different slopes before and after 2016 reflect the fact that the measured cash shares prior to 2016 are not strongly compatible with the reverse Gompertz S-curve used in the forecast, indicating the degree to which this assumption differs from the data. ${ }^{20}$

All cash shares, except for India, are forecast to fall over 2016 to 2026. Table 2 shows the beginning and ending cash shares. The two largest reductions were for Germany (20 pp) and a tie between Japan and Singapore (17 pp). The two smallest reductions were for India (0) and Norway $(6 \mathrm{pp}) \cdot{ }^{21}$ Norway and Singapore had cash shares in the market for cash of 10 percent or less in 2016. The forecast for 2026 adds Australia, China, Denmark, and Japan to this group (for six out of the eleven countries we cover).

The average annual reduction over the forecast period is $13.5 \mathrm{pp}$. Aside from Germany and India, which had the largest and smallest cash share reductions, most of the other countries are not far from the average cash share reduction of $1.4 \mathrm{pp}$ a year. This is almost two-thirds of the yearly rate of the CASHSHARE reduction observed over 2006-2016 (at $2.2 \mathrm{pp}$ ). If accurate, this change would be-as expected - slower over time since (1) specifies a reverse S-curve rather than a linear projection. That is, the reduction in the share of cash use should fall but at a slower rate as it approaches saturation (zero or minimal use). ${ }^{22}$

\footnotetext{
${ }^{20}$ The curves would look connected and smooth over the entire 2006-26 period if (1) was re-estimated using the observed $\left(\mathrm{S}_{\mathrm{t}}\right)$ plus the forecasted $\left(\mathrm{S}_{\mathrm{t}}{ }_{\mathrm{t}}\right)$ cash shares. But then there would be no indication of how closely the observed data was to the assumed functional form in (1).

${ }^{21}$ Numbers in the table have been rounded off.

${ }^{22}$ If a ruler or a simple linear equation were used to forecast cash use, at some point cash use would become negative. A logistic curve avoids this result.
} 


\section{Table 2. Predicted Cash Shares for the CASHSHARE measure for 2016 and 2026}

\begin{tabular}{|l|c|c|c|}
\hline Country & $\mathbf{2 0 1 6}$ & $\mathbf{2 0 2 6}$ & $\begin{array}{c}\text { Yearly pp } \\
\text { Reduction }\end{array}$ \\
\hline Australia & 21 & 10 & 1.1 \\
\hline China & 18 & 3 & 1.5 \\
\hline Denmark & 24 & 9 & 1.5 \\
\hline Germany & 69 & 49 & 2.0 \\
\hline India & 46 & 46 & 0 \\
\hline Japan & 22 & 5 & 1.7 \\
\hline Netherlands & 29 & 14 & 1.5 \\
\hline Norway & 10 & 4 & 0.6 \\
\hline Singapore & 26 & 9 & 1.7 \\
\hline U.K. & 24 & 14 & 1.0 \\
\hline U.S. & 29 & 20 & 0.9 \\
\hline Average & $\mathbf{2 9}$ & $\mathbf{1 7}$ & $\mathbf{1 . 4}$ \\
\hline
\end{tabular}

Source: Author's calculations.

\section{Past Changes in Payment Use}

The speed of adoption and ultimate market share of a significant new way of making payments depends on various attributes (primarily cost and convenience) in competition with attributes of payment instruments already used for similar transactions. This is evident in past substitutions of one class of payment instruments for another over time. A list of major changes in payment instrument use bears this out and indicates the importance of convenience, user cost, or supplier cost, as the incentive for the change.

Cash and Checks to Credit Cards. Prior to and after WWII, checks and giro transactions replaced cash for employee disbursements and consumer bill payments. However, in the 1940s and 1950s when traveling away from home, U.S. travelers found it difficult to use a check to pay for hotel and restaurant services or even for gas. ${ }^{23}$ Typically, cash had to be used. American Express saw a need for a pre-paid, and therefore guaranteed, payment instrument in place of cash. This was the traveler's check. The cost was about 1 percent of the value purchased (e.g., US\$1 per US\$100 traveler's check). This was also the start of credit cards: Diner's Club cards, aimed at business travelers, eventually led to Visa and MasterCard aimed at a broader

\footnotetext{
${ }^{23}$ As a debit instrument, hotels, restaurants, and gas stations could not be sure that a check would actually be paid as it could be returned to them unpaid. This concern was less for checks drawn on local banks close to home.
} 
population segment. At the time, large retail chain stores already had their own check cashing cards and (later) credit cards to make it easier for customers to pay without cash. Cards spread to Europe and other countries, reducing cash and check use there as well. As card use grew, interchange fees became (and still are) a significant retailer operating cost in most countries. ${ }^{24}$

(ii) Paper Credit Card slips to Electronic Payments. Like traveler's checks, credit card payments were guaranteed (if fraud mitigation procedures were followed). However, the process was cumbersome, and retailers had to deposit the paper slips at their bank to get paid (just like cash). Even so, the process was more timely for retailers in check-using countries since depositing a check, especially a non-local check, often took three to five days to be processed, presented, and paid, and another two or more days for the funds to be released to the depositor (to see if the check would be paid rather than returned). Difficulties with paper credit card slips eventually led to electronic card payments at terminals. This increased convenience of use for both consumers and retailers (less time at the POS to complete a payment, no need to deposit paper credit card slips). Electronic processing lowered card issuer costs compared to processing paper slips. The success of lowering processing cost from substituting electronic credit card payments for paper credit card slips led banks to develop an electronic version of a paper check - the debit card.

(iii) Paper Giro Payment Orders to Electronic Giro Payments. In Europe, paper giro payment orders (a credit transfer) were shifted to electronic payments. This speeded up payments and reduced float. It also lowered costs, similar to when many checks in Europe and elsewhere were converted to electronic direct deposits via $\mathrm{ACH} /$ giro networks for employee payroll or overnight credit transfers among banks.

(iv) Mobile Phone-Initiated Payments. More recently, many credit card and/or debit card payments are now made by a mobile phone rather than by swiping (or tapping) a card at a terminal. This is said to be more convenient than using a card at a terminal. In some countries, stored value mobile phone payments substitute for cash largely due to a lack of banking offices and ATMs and circumvent a limited ability to withdraw cash, especially in Africa. It is simply more convenient and, in the case of China, mobile phone payments are tied to the two largest suppliers of products purchased over the Internet. This was then extended to retail stores and suppliers of other services (in competition with bank cards and cash).

(v) Coins to Replace Currency. Canada and the U.S. have had different results trying to replace their C\$1 and US\$1 bills with a C\$1 or US\$1 coin. The goal was to lower

\footnotetext{
${ }^{24}$ The shift from checks to electronic card payments in Norway was accomplished by banks charging a relatively high price for the use of checks by depositors. This pricing policy was encouraged by the central bank to improve the cost efficiency of the payment system.
} 
issuer cost since, at that time, currency might last only 18 months while the lifetime of a coin was estimated to be around 30 years. Canada pushed acceptance of the C\$1 coin by removing the $\mathrm{C} \$ 1$ bill from circulation. The U.S., instead, did not remove the US\$1 bill from circulation (partly due to the fact that use of U.S. currency overseas is estimated to be 55 percent of the value in circulation). As a result, the U.S. now has over US $\$ 1$ billion of unused US $\$ 1$ coins sitting in Federal Reserve vaults. ${ }^{25}$ Europe's experience of replacing low denomination currency with coins mirrors that of Canada. It was successful because it removed the currency from circulation leaving cash users no choice but to accept the coin replacements.

(vi) Internet-Initiated 24/7 Payments. The U.K. adopted Faster Payments (so-called immediate or instant payments) to improve the cost efficiency of their check system and speed up payee access to funds. Faster Payments offer Internet-initiated credit transfer payments (using a computer or mobile phone). ${ }^{26}$ Payments can be initiated 24/7. Crediting of a receiver's account with funds is "immediate," but back office settlement is slightly delayed. So far, only the U.K. has had much experience with this change in payment instrument use but for person-to-person payments, it has already replaced many cash payments.

A common attribute among these earlier payment innovations was a significant increase in user convenience, or retailer/business convenience, or both—at no apparent (long-term) increase in user or supplier cost. Indeed, in many cases, the primary goal was reduced supplier and business cost. For cards versus cash, increased convenience is key, as there is no need to go to an ATM or bank to obtain funds. In addition, retailers and billers cover the direct cost of supplying cards and processing card payments, not users. While card costs are folded into the price of the product or service provided, as occurs when users pay with a check, $\mathrm{ACH}$, or giro transaction, card costs for retailers are often quite large. ${ }^{27}$

\section{Why Cash is Falling}

How well does the passage of time $(t)$ "explain" the variation in the share of cash use $\left(\mathrm{S}_{\mathrm{t}}\right)$ ? As seen from the graphs in Figure 2, many of the plotted cash shares for our preferred measure (CASHSHARE) are almost straight lines. The passage of time over 2006-16 is also a straight line $(1,2,3, \ldots, 11)$. In the simple regression $\mathrm{S}_{\mathrm{t}}=\mathrm{a}+\mathrm{b}$ t, the $\mathrm{R}^{2}$ values are .89 for India and Singapore, .94 for the U.S., but are between .97 and 1.00 for the remaining nine

\footnotetext{
${ }^{25}$ Manufacturing cost is US\$.30 while the face value is $\$ 1$ (National Public Radio Newscast, 2011).

${ }^{26}$ Developments in fast payments are discussed in Bech et al., (2017) and CPMI (2016).

${ }^{27}$ The cost to U.S. merchants for accepting Visa and MasterCard credit cards in 2017 was US\$ 43 billion (Andriotis and Glazer, 2019). This does not include interchange fees from accepting debit cards where, due to legislation, these fees were recently reduced by close to 50 percent (but partly offset by rising bank fees elsewhere).
} 
countries. Thus, the fit is quite high (although the sample size is small). There is not much left over to be explained by an additional variable affecting cash use (such as the interest rate).

Surveys show that younger adults use cards and mobile phones to make payments more often than older adults and consequently use less cash. The average (live) birth rate across our 11 countries is 1.2 percent a year while the average death rate is 0.8 percent. As younger adults enter the population (equal to the birth rate) and older adults leave it (equal to the death rate), the average composition of the population changes by 2 percent a year. In 2006, this change is 2 percent. The change in population by 2007, relative to 2006, is 4 percent. By 2008 , the change in population composition is 6 percent and so on out to 2016 where the cumulative change is 22 percent. Demographic change (assumed to be a constant $\mathrm{C}=2$ percent each year) is $\mathrm{C} \times 1$ for $2006, \mathrm{C} \times 2$ for 2007 , and so on. Over 11 years it is $\mathrm{C} \times$ $(1,2,3, \ldots, 11)$ and forms a linear series like time $1,2,3, \ldots, 11 .{ }^{28}$ For individual countries the sum of the birth rate and death rate ranged from 1.3 percent in 2006 (Singapore) to 2.6 percent (India). For both Denmark and Norway it was 2 percent in 2006 . The crosscountry average was 1.98 percent for 2006 and rounds to 2 percent.

Demographic change over all 11 countries, as well as for each country individually, is a linear series. As both time and the sum of the birth and death rates both form a linear series, the result from running $S_{t}=a+b$ (birth rate + death rate) for each country gives the same high $\mathrm{R}^{2}$ values as achieved using time $(\mathrm{t})$ above.

While any linear series regressed on $\mathrm{S}_{\mathrm{t}}$ would give the same strong fit, the demographic explanation presented here is supported by two facts. First, surveys show that young adults use more cash substitutes and less cash than do older adults. Second, the change in the composition of the population — new entrants plus new exits - both work to decrease the use of cash in a country, although the rate of change varies across countries.

Card and mobile phone payments in some countries are so popular that some retailers actively discourage cash payments. Accepting cash requires employees to carefully account for the amounts received and deposited overnight at a bank or kept at a store (and is a temptation for robbery). ${ }^{29}$ As popular as they are, the card industry is vulnerable to an alternative payment instrument that has a lower cost of acceptance. This includes instant payments via the Internet and mobile phones using phone numbers tied to deposit accounts. As well, retailers and billers would be quite interested in a CBDC instrument that had a lower cost of acceptance than cards (if that could be arranged).

\footnotetext{
${ }^{28}$ Birth and death rates do change slowly over long periods of time but in this application it is assumed they are constant over 2006-2016. This is close to the truth for almost all of the countries we cover.

${ }^{29}$ Alternatively, accepting cash at the POS or for personal services (house repairs and upkeep) is an opportunity for tax evasion in countries with high taxes.
} 


\title{
VI. Benefits And Costs of Central Bank Digital CuRRency
}

\begin{abstract}
A. Benefits ${ }^{30}$
Digital cash has two important benefits. One is a reduction in the cost of supplying cash to the public. The other is the possibility, depending on how digital cash is implemented, of greater user convenience. ${ }^{31}$ If digital cash substitutes for currency, the expense of printing currency, maintaining its fitness, building vaults and storage depots, and distributing cash would be markedly reduced. ${ }^{32}$ As the difference between these costs and the face value of currency represent seigniorage revenues, these revenues would be retained if digital cash replaces currency.
\end{abstract}

The greater convenience of digital cash depends on the method of access. Certainly, there is little improvement in convenience if a user has to travel to an ATM or bank branch weekly or biweekly to reload a digital cash card or a mobile phone. However, if central banks issue a digital cash card, POS terminals could be adjusted to accept it just like a bank debit card. Funds could be debited from a user's bank deposit account for each transaction. Or, like cash back at the POS, inserting a central bank card into a retailer's terminal could both pay for a transaction using bank deposit money as well as store cash on the card (up to a given level) for future purchases. Either arrangement would be an improvement in convenience. Accessing digital cash would be less costly for banks than their current expense in providing it. As a result, central banks could argue that no bank fees should be assessed for processing these transactions.

A different issue facing central banks is: would the shift to digital cash be large enough for achieving other policy goals? Some argue that digital cash could provide a check on the market power of providers of cards and other substitutes for cash. Although access to cash through a bank deposit account could achieve this goal, it would not provide an alternative payment network in the event of a natural disaster or severe disruption of a privatelyoperated payment network.

\footnotetext{
${ }^{30}$ A more involved discussion of digital cash is available in: Ali, et al. (2014), Barontini and Holden (2019), Barrdear and Kumhof (2016), Bech and Garratt (2017), Carstens (2018), CPMI (2015, 2018), Danmarks Nationalbank (2017), Engert and Fung (2017), He, et al. (2017), Kumhof and Noone (2018), Mancini-Griffoli, et al. (2018), Norges Bank (2018), Rogoff (2015), Sveriges Riksbank (2018, 2017), and Yao (2018).

31 Another benefit concerns access to a risk-free payment instrument. This could increase the demand for CBDC if banks are not trusted and/or adequate deposit insurance is not available.

${ }^{32}$ For illustration, the U.S. Federal Reserve Board currency budget for 2018 was USD 862 million. This covered currency printing by the Bureau of Engraving and Printing, maintaining currency fitness, vault costs, protection, plus some transportation by Federal Reserve Banks, along with counterfeit deterrence.
} 
A way to achieve both goals, however, would be to supply digital cash through user deposits at the central bank. These deposits would be accessed using a cash card, mobile phone, or computer (via the Internet). While this is more convenient than withdrawing cash today, its only improvement over bank-supplied payment instruments would be the presumed safety of its deposits. Central banks cannot fail while private banks can. Even so, the availability of an effective deposit insurance program would remove this apparent advantage.

If users had a deposit at the central bank, processing digital cash transactions could be done independently from privately-operated processing centers. While this may sacrifice scale benefits of processing digital cash transactions with (say) bank card transactions at a privately-operated processing center, digital cash could operate as an independent and substitute payment network in the event of national disasters or operational disruptions in the private sector. ${ }^{33}$ However, this is not the only way to insulate an economy from payment system disruptions. An alternative is already in place for large value wire transfers in Europe (Target) and the U.S. (Fedwire). This involves a duplicate processing center processing the same transactions in real-time as a back-up, as well as alternative communication links and other disaster recovery procedures.

It is possible that having a deposit at the central bank may, with some work, permit the bank to have greater monetary control of the economy. The central bank determines the interest rate paid on its deposits or loaned to banks and, the argument goes, can reduce it below the zero lower bound. If central banks paid negative interest rates on their deposits, a way would still have to be found to require banks to do the same-perhaps by moral suasion or temporary regulation. Experiencing a lower deposit-loan rate spread, and correspondingly lower profits, may be insufficient to induce banks to pay negative rates on customer deposits if negative rates are believed to be temporary. If significant amounts of cash were still in circulation, both banks and central banks may also have to impose a fee on the withdrawal of currency. ${ }^{34}$ But even without any currency, the withdrawal of digital cash would also have to be limited or charged for. ${ }^{35}$

Accessing digital cash through a commercial bank or through a central bank clearly improves user convenience relative to withdrawing cash today. But this makes digital cash just equivalent to a debit card. Increased convenience alone is unlikely to generate enough demand for digital cash that it reduces the use of bank cards or other cash substitutes. It may

\footnotetext{
${ }^{33}$ Major operational disruptions of international card networks are rare. Even so, Europe's VISA payment network experienced a hardware failure (June 2018) leading to an outage that affected cardholders in the region. MasterCard also experienced an outage problem (July 2018).

${ }^{34}$ Buiter (2009) and Humphrey (2015) have some suggestions in this regard.

${ }^{35}$ Depositors accept that they cross-subsidize borrowers when interest rates are low, and banks put up with lower spreads. But going deep into negative territory risks greatly encouraging borrowing for speculative purposes (e.g., housing) unless other controls (credit allocation) are adopted.
} 
not even be attractive enough to replace the value of cash currently being used in a country. If CBDC is just as good as a bank debit card, why switch? Why have two ways of making the same payment when one will do just fine? ${ }^{36}$ This isn't exactly true, since in some countries retailers won't accept a bank card for very small payments due to the interchange fee. In other countries mobile phones are commonly used for even small payments.

Thus, the interchange fee for accepting a digital cash payment in some countries could be an important issue in the adoption of digital payments. There is no interchange fee for paying in cash. And retailer expenses in accepting digital cash would be less than their current cost to accept physical cash. If the interchange fee for accepting digital cash was zero, many retailers would likely find a way to induce users to use a digital cash card instead of a bank debit card (e.g., giving a reward for use). If interchange fees are already very low, they would still save costs by accepting CBDC since the costs of accepting cash would be eliminated. Added to the increased convenience of digital cash, how it is priced to retailers, and their response, would be important in determining the demand for digital cash by potential users. However, many central banks do not provide payment services that are competitive with private banks. Using tax revenues to finance such competition, if digital cash is provided without charge to retailers and billers, could raise political issues in some countries.

CBDC should be far less controversial in a country where cash use is still very important for a wide range of transactions and substitutes for cash are relatively new and not firmly established. This is where the availability of CBDC should have its greatest acceptance. In many OECD countries, bank cards and other cash substitutes are ubiquitous: users have already made a choice between cash and cash substitutes and have largely chosen the latter. In countries that heavily use cash, that choice is still to be made. The fact that CBDC would improve convenience over physical cash and be just as good as a bank debit card-but not better-is a definite advantage in a country where bank cards and e-money are in short supply or have yet to be widely introduced.

\section{B. Costs}

The costs of digital cash depend primarily on how it is structured and implemented. While the overall expense is believed to be much lower than providing all the functions associated with physical cash, the expense would be lower still if digital cash was obtained by debiting a user's bank deposit account (as currently occurs with cash). This alternative would preserve the ability of users to receive bank interest while at the same time lower central bank operating cost for digital cash.

The expense of setting up, maintaining, and processing digital cash payments through (new) central bank deposit accounts would be markedly higher. This would rise if interest was paid

\footnotetext{
${ }^{36}$ This was one of the reasons why the reloadable cash card experiment in Europe did not gain sufficient traction (Van Hove, 2006).
} 
on central bank deposits, although investing the funds in government securities would largely (or fully) offset this expense. Still, paying interest is likely necessary to attract deposits away from banks to begin with. Indeed, if interest is not paid on central bank deposits, the only incentive to use digital cash is that accessing cash would be more convenient than withdrawing it a few times a month via an ATM.

Establishing central bank deposit accounts can have other effects. If a significant share of bank deposits shifted to the central bank, the bank supply of low cost funding would fall, raise funding cost, and lower bank credit creation. To maintain a profitable spread between higher funding cost and loan revenue, banks may respond by marginally increasing their risk exposure. Such a situation existed prior to the Great Depression in the U.S. Some historians argue that competition for bank deposits exacerbated the Depression, leading in some countries to restrictions on interest rates banks could pay. Alternatively, history shows that banks, non-bank financial firms, and their regulators are perfectly capable of creating conditions for a financial crisis without interest rate driven competition for deposits (c.f., the recent Great Recession).

Although competition for deposits between banks and a central bank can have consequences for the pace of credit creation, just as occurs when interest rates rise, this need not have important consequences for economic growth. A reduced pace of bank-funded credit creation may well be offset by expanded credit creation by non-bank financial firms. Perhaps the real concern here is that non-bank financial firms are not as well supervised as banks and tend to take riskier positions.

Box 2 provides a summary of CBDC studies in a few selected countries. Some have considered the use of CBDC with tokenized security assets to enable delivery versus payment in financial markets. Central banks have also collaborated to explore how wholesale central bank digital currencies could be used to facilitate cross-border payments (Bank of Canada, et al., 2018). 


\section{Box 2. Central Bank Digital Currency Studies in Selected Countries}

Canada. The Bank of Canada has provided analytical work on digital cash to explore the use of digital representations of the Canadian dollar (called digital depository receipt) for making wholesale payments under Project Jasper (Chapman et al., 2017; Engert and Fung, 2017; Fung and Halaburda, 2016). The Bank of Canada, Bank of England, and the Monetary Authority of Singapore have also cooperated to explore future models of cross-border interbank payments and settlements (Bank of Canada et al., 2018).

China. The People's Bank of China established the Institute of Digital Money in 2017 and has published a systematic framework to understand CBDC. The institute is investigating a set of new and reportedly superior payment features, compared to existing privately-issued digital cash, the specifics of which have not been disclosed (Yao, 2018).

Denmark. Danmarks Nationalbank have provided analytical work on the pros and cons of a CBDC in DK. Nationalbanken finds that in the Danish case the risks connected with issuing CBDC outweighs the potential benefits for society. At present, the central bank therefore has no plans to issue digital cash (Danmarks Nationalbank, 2017)

Norway. A decision to issue CBDC would be based on a socio-economic cost-benefit analysis. The central bank will continue to issue cash if there is a demand for it. If usage declines to very low levels, digital cash could be an alternative to deposit money to ensure confidence in cash and the monetary system. If issued, digital cash should be structured to avoid impairing the ability of banks and other financial institutions to provide credit (Norges Bank, 2018).

Singapore. Project Ubin involved experimentations using digital representations of the Singapore dollar for making domestic interbank payments. It was extended to delivery versus payments against tokenized assets and include cross-border payments (Deloitte and Monetary Authority of Singapore, 2017; Deloitte et al., 2018; Monetary Authority of Singapore and the Association of Banks in Singapore, 2017).

Sweden. No decision has been made to issue CBDC, although a pilot (e-krona) is planned to assess the technical operating features of digital cash, certain legal issues, and the impact on the central bank's balance sheet as well as monetary policy. By functioning independently from the infrastructure used by the commercial bank system, the e-krona system could make the payment system more robust in the event of operational disruptions. If issued, e-krona would be targeted for smaller payments and serve as a direct claim on the central bank. It would not pay any interest on central bank deposits initially and offer off-line payment features for groups that do not desire or are ineligible for e-krona accounts (Sveriges Riksbank, 2017; 2018).

United Kingdom. The Bank of England has explored the macroeconomic impact of central bank issued digital currencies, and their design principles and balance sheet implications (Barrdear and Kumhof, 2016; Kumhof and Noone, 2018). 


\section{SUMMARY AND CONCLUSIONS}

Four estimates of the use of physical cash in 11 countries over 2006-16 are presented. One is rejected as misleading, and one is used to forecast how the use of cash may change out to 2026. Estimates of current cash use are from simple direct calculations of three somewhat different measures of cash use. All of the three are missing certain data, which is unavailable. These three measures are shown for each country in figures and their trends are fitted using a cubic spline. They suggest that average cash use across 11 countries is falling by an average of 1.3 percent to 2.2 percent a year. Logistic curves are used to obtain cash share forecasts going forward. The average reduction in cash use out to 2026 is forecast to slow to 1.4 percent a year. The slower reduction is due to the functional form adopted for the forecast.

Without a digital version of cash, it is possible that over time cash use will be almost wholly replaced by substitute instruments tied to private bank deposit money. For digital cash to be a success, there has to be an incentive to adopt it. For users, that incentive is greater convenience by not having to travel to an ATM or bank branch to withdraw cash. This makes CBDC only as convenient as a bank debit card—not better.

Without an additional incentive, the upper limit to the demand for central bank digital currency is likely to be below that of the current level of physical cash. Earlier efforts in Europe and the U.S. to replace cash with a reloadable cash card were dropped largely because few saw the need for a reloadable cash card when cash was already in their wallet. A similar view likely applies to digital cash: why have a digital cash card (or mobile phone app) when a person can do the same things and have the same convenience with a bank debit card (or mobile phone app)?

Surveys show that younger adults use more cards and mobile phones than cash to make payments while for older adults it is the reverse. As younger adults enter the population, and older adults leave, this not only changes the average composition of the population of our 11 countries by 2 percent annually, it necessarily reduces the overall use of cash in the population. Thus, normal demographic change, coupled with a preference for non-cash payments by the younger portion of the population, is sufficient to explain the 1.3 percent to 2.2 percent yearly average reduction in cash use across our eleven countries. This implies that the younger portion of the population will have to change their current preference for non-cash payments if CBDC is to be viable in the long run. Unfortunately, this group evidences the strongest preference for non-cash payments.

One possible incentive for this and other groups to adopt digital cash could be for central banks to provide it at no cost to those that use it or retailers and billers that accept payments from it. With a zero interchange fee on digital cash, along with a reduction/elimination in the cost of accepting cash, some retailers would find a way to encourage consumers to adopt and 
use it. However, using tax revenues to finance central bank competition with private banks could raise political issues in some countries.

This has implications for other central bank policy goals. These are the possibility that digital cash would function as a substitute payment network that would (i) operate during natural disasters or when other payment instruments encounter severe operational problems and/or (ii) provide a check on the market power of suppliers of other payment instruments. If the long-term viability of digital cash is not assured, then neither are these two related policy goals.

It is worth investigating how the survivability of the various privately-operated payment networks can be assured in the face of unexpected operational problems. This has been done for both Europe's Target and the U.S.'s Fedwire wire transfer payment networks. As well, stronger antitrust enforcement, focused on comparing costs with prices charged for various payment services, may be a more effective way of achieving the second policy goal. 


\section{REFERENCES}

Ali, Robleh, John Barrdear, Roger Clews, James Southgate (2014). The Economics of Digital Currencies, Bank of England, Quarterly Bulletin, Q3/2014.

Andriotis, AnnaMaria and Emily Glazer (2019). Banks Pull Back on Reward Cards, Wall Street Journal, January 2, p. A1.

Bagnall, John., David Bounie, Kim Huynh, Anneke Kosse, Tobias Schmidt, Scott Schuh, and Helmut Stix (2014). Consumer Cash Usage: A Cross-Country Comparison with Payment Diary Survey Data, Working Paper No. 14-4, Consumer Payments Research Center, Federal Reserve Bank of Boston, May 8.

Bank of Canada, Bank of England, Monetary Authority of Singapore (2018). Cross-Border Interbank Payments and Settlements-Emerging Opportunities for Digital Transformation, November.

Barontini, Christian and Henry Holden (2019). Proceeding with Caution-A Survey on Central Bank Digital Currency, BIS Papers, No. 101, January.

Barrdear, John and Michael Kumhof (2016). The Macroeconomics of Central Bank Issued Digital Currencies. Bank of England Staff Working Paper No. 605, July.

Bech, Morten, Umar Faruqui, Frederik Ougaard, and Cristina Picillo (2018). Payments are A-Changin' But Cash Still Rules, BIS Quarterly Review, March, pages 67-80.

Bech, Morten and Rodney Garratt (2017). Central Bank Cryptocurrencies, BIS Quarterly Review, September, pages 55-70.

Bech, Morten, Yuuki Shimizu, and Paul Wong (2017). The Quest for Speed in Payments, BIS Quarterly Review, March, pages 57-68.

Buiter, Willem (2009). Negative Nominal Interest Rates: Three Ways to Overcome the Zero Lower Bound. NBER Working Paper, No. 15118, National Bureau of Economic Research, Cambridge.

Carstens, Agustín (2018). Money in the Digital Age: What Role for Central Banks? Lecture at House of Finance, Goethe University, Frankfurt.

Chapman, James, Rodney Garrat, Scott Hendry, Andrew McCormack, and Wade McMahon (2017). Project Jasper: Are Distributed Wholesale Payments Feasible Yet? Bank of Canada Financial System Review, June.

Committee on Payments and Market Infrastructures and Markets Committee (2018). Central Bank Digital Currencies, March, Bank for International Settlements. 
Committee on Payments and Market Infrastructures (2017a). Statistics on Payment, Clearing and Settlement Systems in the CPMI Countries-Figures for 2016, December, Bank for International Settlements.

Committee on Payments and Market Infrastructures (2017b). Methodology of the Statistics on Payments and Financial Market Infrastructures in the CPMI Countries (Red Book Statistics)., August, Bank for International Settlements.

Committee on Payments and Market Infrastructures (2016). Fast Payments-Enhancing the Speed and Availability of Retail Payments, November, Bank for International Settlements.

Committee on Payments and Market Infrastructures (2015). Digital Currencies, Bank for International Settlements.

Danmarks Nationalbank (2017). Central Bank Digital Currency in Denmark? 15 December, No. 28.

De Nederlandsche Bank and the Dutch Payments Association (2017). Point of Sale Payments in 2016.

Deloitte, Singapore Exchange, and Monetary Authority of Singapore (2018) Delivery Versus Payment on Distributed Ledger Technologies: Project Ubin.

Deloitte and Monetary Authority of Singapore (2017). Project Ubin: SGD on Distributed Ledger.

Deutsche Bundesbank (2018). Payment Behavior in Germany in 2017-Fourth Study of the Utilization of Cash and Cashless Payment Instruments, February 9.

Doyle, Mary-Alice, Chay Fisher, Ed Tellez, and Anirudh Yadav (2017). How Australians Pay: Evidence from the 2016 Consumer Payments Survey, Reserve Bank of Australia, Research Discussion Papers, 2017-04.

Engert, Walter and Ben Fung (2017). Central Bank Digital Currency: Motivations and Implications, Bank of Canada, Staff Discussion Paper 2017-16.

Esselink, Henk and Lola Hernández (2017). The Use of Cash by Households in the Euro Area, European Central Bank, Occasional Paper Series, No. 201, November.

European Central Bank (2017). ECB Payments Statistics, September.

Flannigan, Gordon and Andrew Staib (2017). The Growing Demand for Cash, Reserve Bank of Australia, Bulletin, September, 63-74. 
Fung, Ben S. C. and Hanna Halaburda (2016). Central Bank Digital Currencies: A Framework for Assessing Why and How, Bank of Canada Staff Discussion Paper 201622.

Fung, Ben, Kim P. Huynh, and Gerald Stuber (2015). The Use of Cash in Canada, Bank of Canada Review, 45-56.

Gerdes, Geoffrey, Jonathan Hamburg, May Liu (2016). The Federal Reserve Payments Study 2016: Recent Developments in Consumer and Business Payment Choices, U.S. Federal Reserve System.

Greene, Claire and Joanna Stavins (2018). The 2016 and 2017 Surveys of Consumer Payment Choice: Summary Results, Federal Reserve Bank of Boston, Research Data Reports, No. 18-3.

Greene, Claire, Shaun O’ Brien, Scott Schuh (2017). U.S. Consumer Cash Use, 2012-2015: An Introduction to the Diary of Consumer Payment Choice, forthcoming.

Greene, Claire, and Scott Schuh (2017). The 2016 Diary of Consumer Payment Choice, Working Paper No. 17-7, Consumer Payments Research Center, Federal Reserve Bank of Boston, December 1.

He, Dong, Ross Leckow, Vikram Haksar, Tommaso Mancini Griffoli, Nigel Jenkinson, Mikari Kashima, Tanai Khiaonarong, Celine Rochon, Hervé Tourpe (2017). Fintech and Financial Services: Initial Considerations. IMF Staff Discussion Note 17/05, International Monetary Fund, Washington, DC.

Henry, Christopher S., Kim P. Huynh, and Rallye Shen (2015). 2013 Methods-of-Payment Survey Results, Bank of Canada Discussion Paper 2015-04.

Humphrey, David (2015). Negative Interest Rates and the Demand for Cash, Journal of Payments Strategy and Systems, 9, No. 4, 280-289.

Humphrey, David, Aris Kaloudis, Grete Owre (2004). The Future of Cash: Falling Legal Use and Implications for Government Policy, Journal of International Financial Markets, Institutions and Money, 14, 221-233.

Khiaonarong, Tanai and David Humphrey (2005). Use and Substitution of Cash and Electronic Payments in Asia, The South East Asian Central Banks Research and Training Center, Occasional Paper No. 42.

Kumhof, Michael and Clare Noone (2018). Central Bank Digital Currencies-Design Principles and Balance Sheet Implications. Bank of England Staff Working Paper No. 725, May. 
Mancini-Griffoli, Tommaso, Maria Soledad Martinez Peria, Itai Agur, Anil Ari, John Kiff, Adina Popescu and Celine Rochon (2018). Casting Light on Central Bank Digital Currency, IMF Staff Discussion Note 18/08, International Monetary Fund, Washington, DC.

Meade, Nigel and Towhidul Islam (1995). Forecasting with Growth Curves: An Empirical Comparison, International Journal of Forecasting, 11, 199-215.

Monetary Authority of Singapore and the Association of Banks in Singapore (2017). Project Ubin Phase 2: Re-Imagining Interbank Real-Time Gross Settlement System Using Distributed Ledger Technologies, November.

National Public Radio Newscast (2011). \$1 Billion That Nobody Wants, https://www.npr.org/2011/06/28/137394348/-1-billion-that-nobody-wants

Norges Bank (2018). Central Bank Digital Currencies, Norges Bank Papers, No. 1/2018.

Payments.com (2018). Global Cash Index: Asia-Pacific Edition, June. (2018). Global Cash Index: Australia Edition, July. (2018). Global Cash Index: India Edition, August. (2017). Global Cash Index: United States Analysis, March. (2017). Global Cash Index: United Kingdom Edition, November. (2017). Global Cash Index: Germany Edition, December.

Rogoff, Kenneth (2015). Costs and Benefits of Phasing Out Paper Currency, National Bureau of Economic Research Macroeconomics Annual, 29(1), 445-456

Schneider, Friedrich, Konrad Raczkowski, and Bogdan Mroz (2015). Shadow Economy and Tax Evasion in the EU, Journal of Money Laundering Control, 18, 34-51.

Schuh, Scott (2017). Measuring Consumer Expenditure with Payment Diaries, Federal Reserve Bank of Boston Working Papers, No. 17-2.

Sveriges Riksbank (2018). The Riksbank's E-krona Project, Report 2, October.

Sveriges Riksbank (2017). The Riksbank's E-krona Project, Report 1, September.

Van Hove, Leo (2006). Why Electronic Purses Should Be Promoted, Banking and Information Technology, Nr.2, June, 20-31. 
Yao, Qian (2018). A Systematic Framework to Understand Central Bank Digital Currency, Science China Information Sciences, Vol. 61, March. 


\section{APPENDIX I. DATA SOURCES AND NoteS}

Payment statistics were obtained from the BIS, ECB, national central banks, and national statistical offices (CPMI, 2017a; ECB, 2017; Danmarks Nationalbank; Norges Bank; and Statistics Denmark). The BIS methodology for defining payment instruments (cards, credit transfers, checks, direct debits, electronic money) and ATM cash withdrawal are followed. ${ }^{1}$ OTC cash withdrawal data were obtained from the ECB. ATM/OTC cash withdrawal information were collected for Australia, Germany, India, U.K., U.S. from the Global Cash Index (Payments.com, various issues). For Denmark, ATM/OTC cash withdrawal estimated values were collected from Danmarks Nationalbank.

Data on gross domestic product and currency in circulation were collected from the IMF International Financial Statistics. ${ }^{2}$ Household final consumption expenditure (including the expenditures of nonprofit institutions serving households) were obtained from World Bank national accounts data and OECD national accounts data files.

Eleven countries are included in the sample: China, Denmark, Germany, India, Japan, Korea, Norway, Singapore, Sweden, United Kingdom, and United States. Annual data was obtained for the period 2006 to 2016. For comparison purposes, national currencies were converted to US dollars using the PPP conversion factor from the 2011 International Comparison Program Database of the World Bank.

Adjustments were made to the statistical data to allow for cross-country comparisons and account for missing data. For Japan, the missing value for electronic money for 2006 was estimated using logarithmic growth rates. Missing values for cards for 2010-11 were calculated with linear interpolation.

Due to data availability and differences in how payment instruments are used across countries, card payments and electronic money were used to approximate the major cash substitutes used in household final consumption expenditures. Cards include domesticallyissued cards for local and overseas purchases, and excludes local purchases from foreignissued cards. In general, a card which has several functions (cash, debit, delayed debit, credit, and electronic money) should not be added to avoid the risk of double counting. In cases

\footnotetext{
${ }^{1}$ The CPMI has revised the methodology for compiling statistics on payments and FMIs (CPMI, 2017b). This has updated and enhanced the indicators on cashless payments to reflect the substantial changes that the payment landscape has undergone over the past decade. The new methodology will in future include more information on the role of non-banks, on online and contactless payments and on fast payments. The revised methodology also clarifies how to count debit and credit cards, and which retail cashless payments count as domestic and which as cross-border.

${ }^{2}$ For Singapore, currency in circulation data was collected from the Monetary Authority of Singapore. For India and the United Kingdom, notes and coins in circulation outside banks were obtained from the BIS.
} 
where certain functions are not indicated separately but grouped together, this should be noted (CPMI, 2017a).

Although not done in this report, a better approximation of the values of other payment instruments in the value of consumption, particularly for country-level analysis, would consider the following:

- For checks, multiplication of the average value per bank card by the number of check transactions for a given year provides an approximation on the value of personal checks and avoids the inclusion of relatively large-value business or corporate checks. This could include big ticket items such arising from the financial markets, or the purchase of land and housing.

- For credit transfers, large-value interbank payments should be excluded. Credit transfers could be widely used by governments and businesses in some countries. ${ }^{3}$

- For direct debits, large-value payments should be excluded. Direct debits could be widely used by governments and businesses in some countries. For example, direct debits could originate from billers, such as insurance and utilities companies to collect regular payments, or from financial institutions when collecting loan repayments. Some enterprises could also use direct debits to collect payments from commercial clients.

Without the above adjustments, if checks, credit transfers, and direct debits were added to the value of card and e-money payments, the value would exceed the value of household final consumption. ${ }^{4}$ This is because checks, credit transfers, and direct debits are not only used for business and government transactions, but also because they are mostly used for big ticket consumptions items that are not commonly paid in cash - and thus are not a cash substitute.

Lastly, most mobile phones are not considered as a payment instrument, but a payment solution associated with a card. Mobile payment offerings could also connect a user's phone number to their bank account, making account-to-account settlements possible. Therefore, the differentiation of mobile payments as a card or credit transfer transaction is important to avoid double counting in statistical reporting.

\footnotetext{
${ }^{3}$ Since the value of these transactions is relatively large, cross-country comparison should be treated with caution. Consequently, CPMI figures related to credit transfers have not been calculated (CPMI, 2017a).

${ }^{4}$ For a discussion of measurement issues relating to consumer expenditures and the analysis of payment diaries, see: Greene et al., (2017), Schuh (2017), and Esselink and Hernández (2017).
} 


\section{APPENDiX II. CASH USE INDiCATORS IN Eleven COUNTRIES, 2006-2016}

The eleven figures shown below illustrate how cash use has varied in 11 countries using three different measures. The beginning (2006) and ending (2016) cash shares, and the percentage point change, for each measure is also shown. The countries covered are Australia, China, Denmark, Germany, India, Japan, Netherlands, Norway, Singapore, the U.K. and the U.S. The CASHSHARE measure is also shown in Figures 2A and 2B so the countries' experience can be more easily compared.

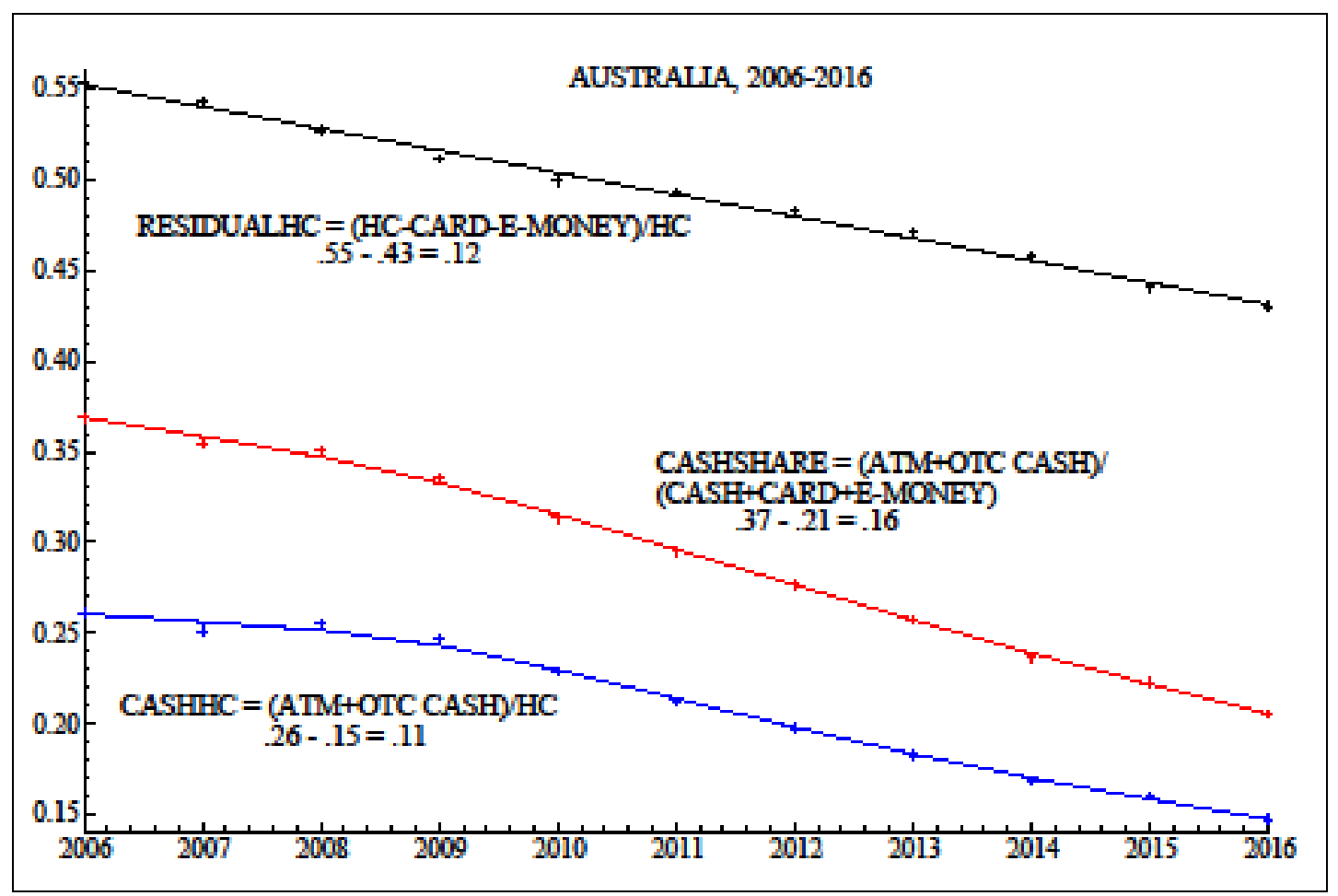

Sources: BIS, World Bank, Payments.com, and author's calculations. 


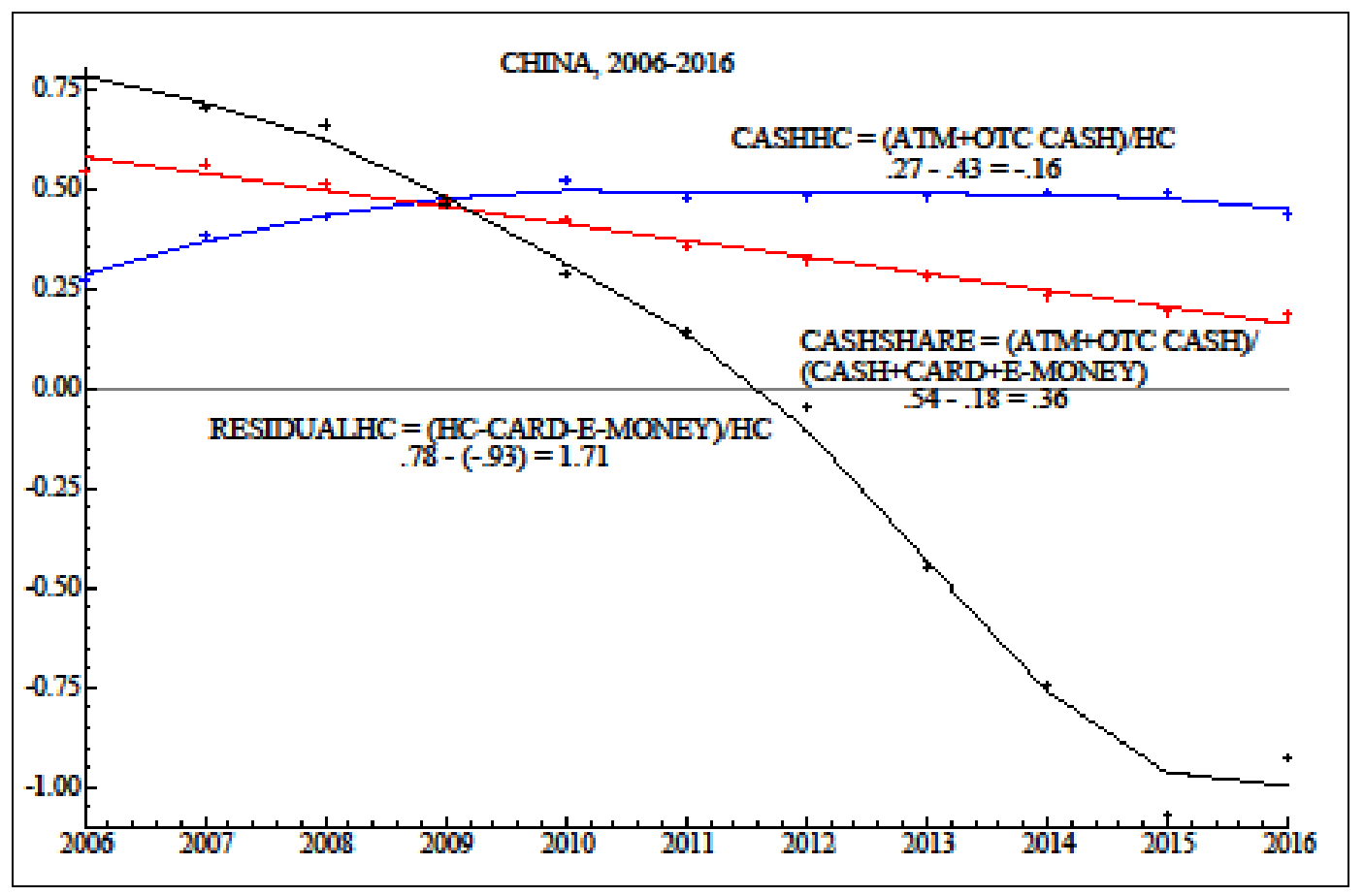

Sources: BIS, People's Bank of China, World Bank, Payments.com, and author's calculations.

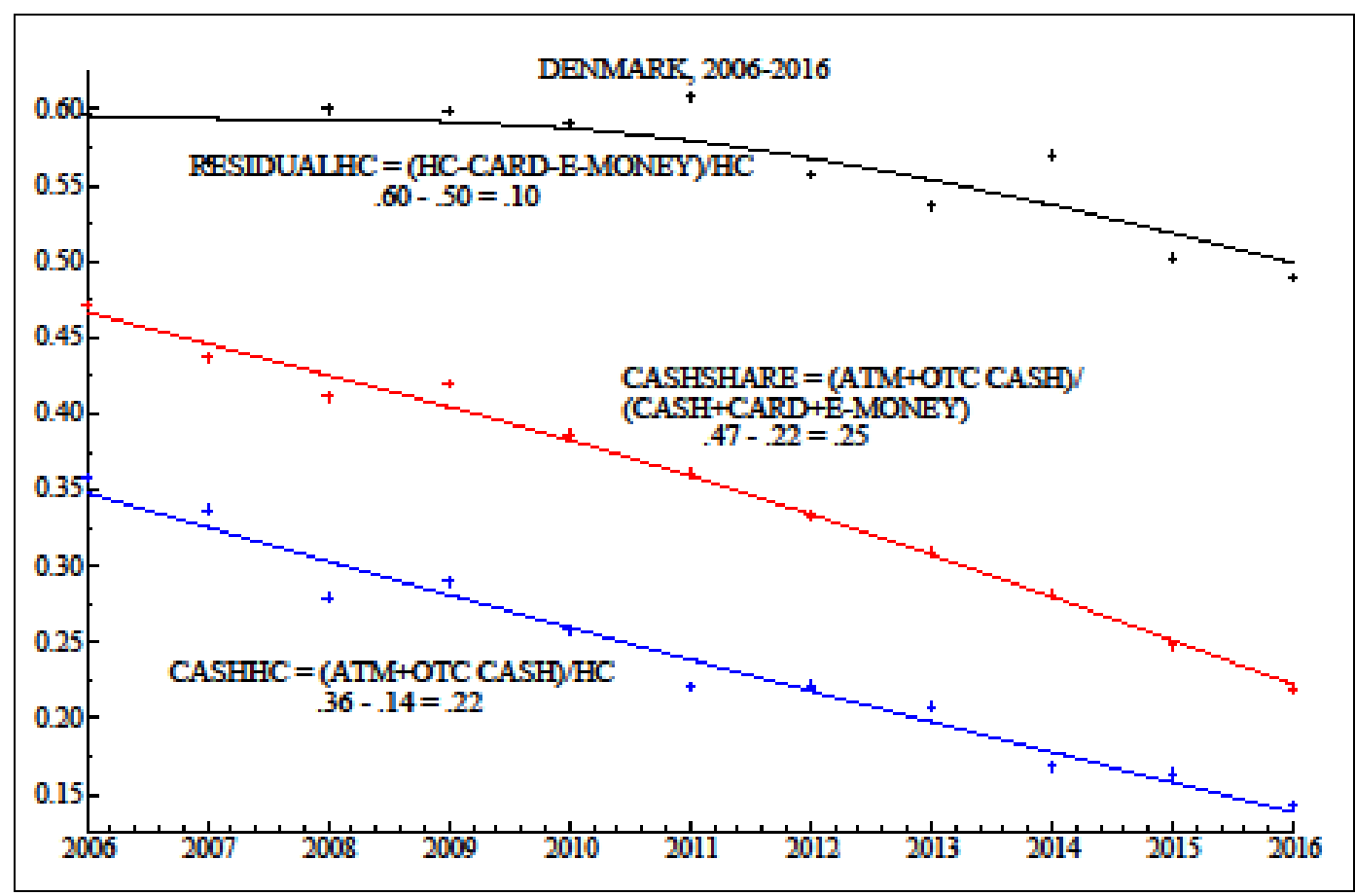

Sources: ECB, Danmarks Nationalbank, World Bank, and author's calculations. 


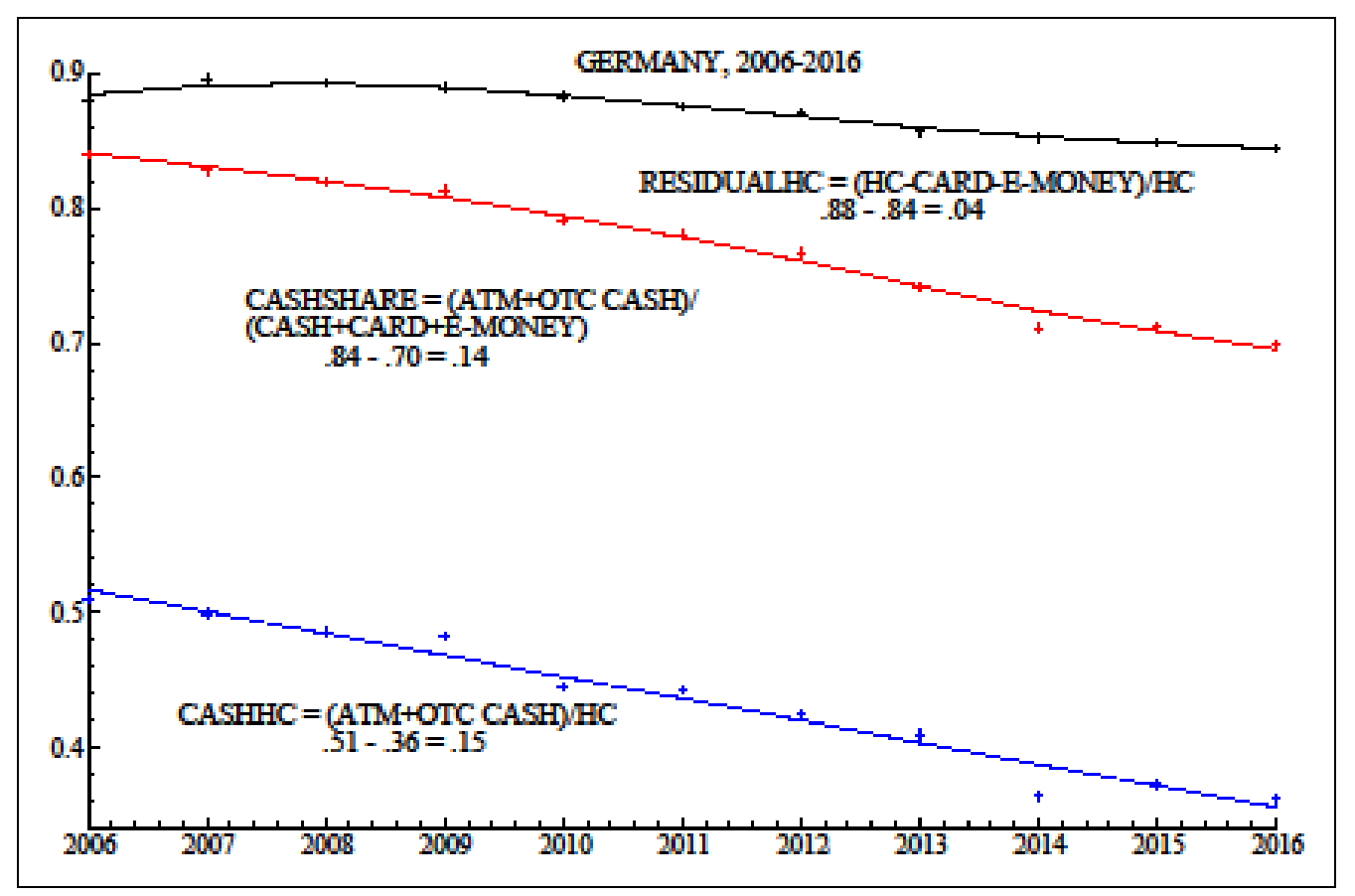

Sources: BIS, ECB, World Bank, Payments.com, and author's calculations.

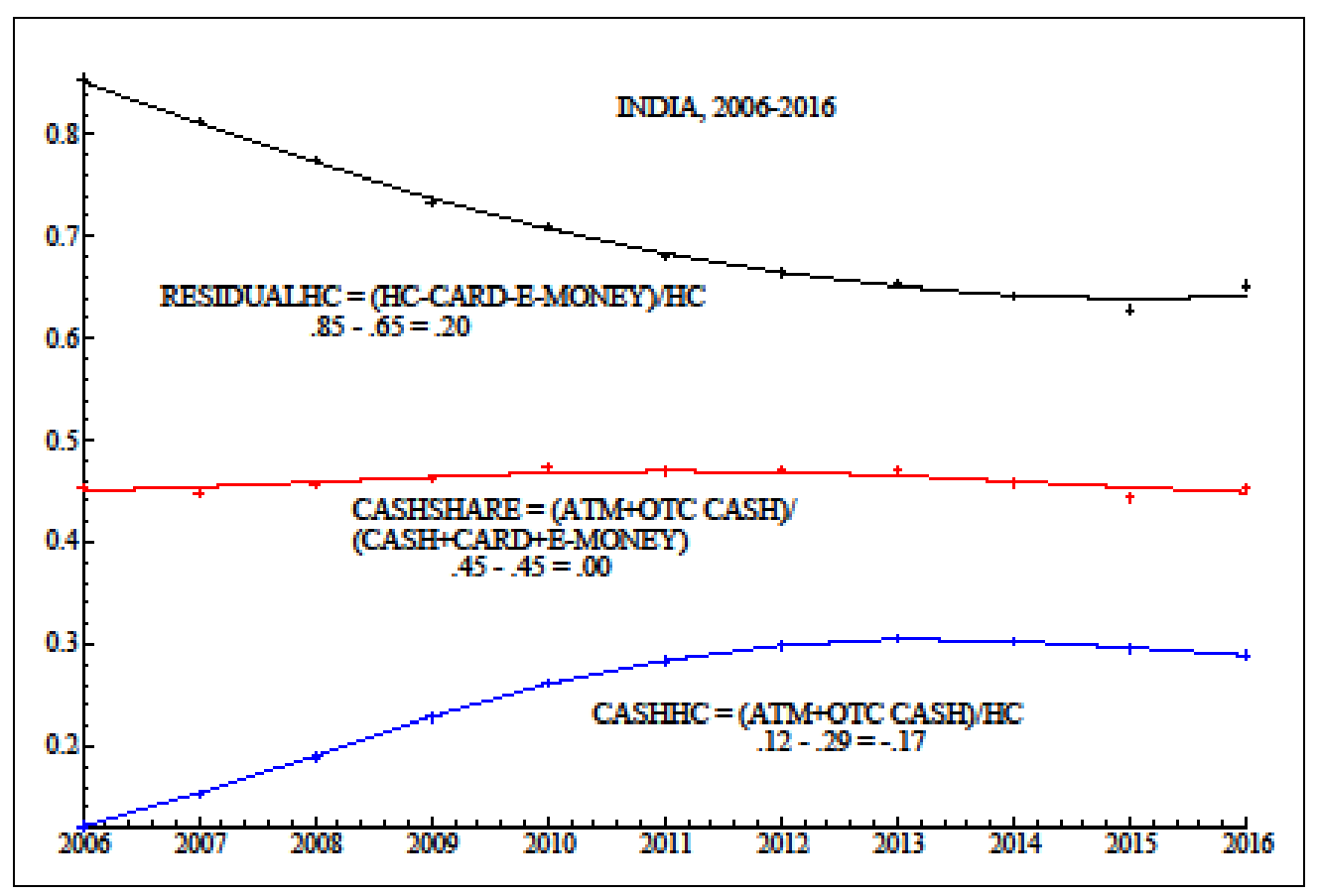

Sources: BIS, World Bank, Payments.com, and author's calculations. 


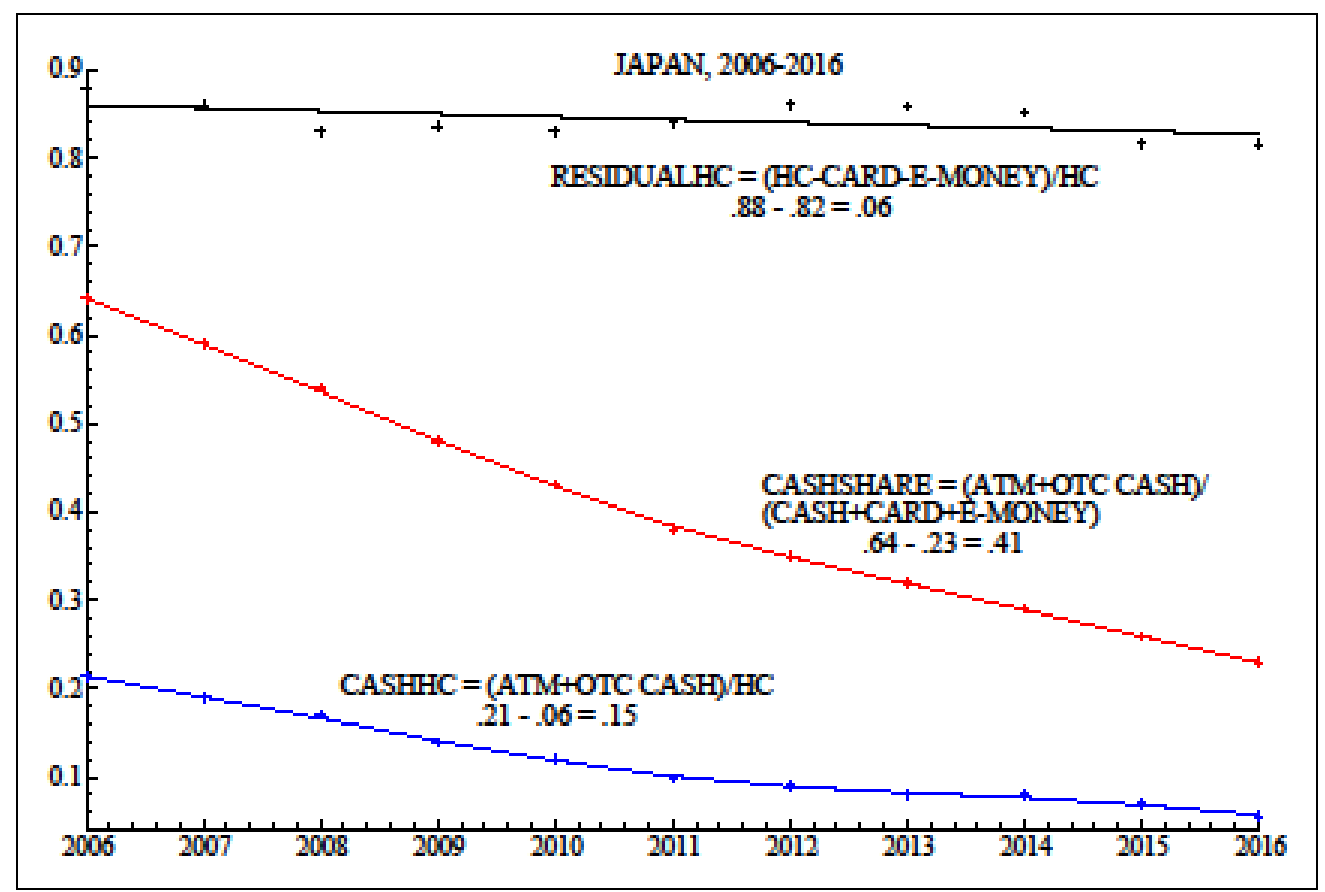

Sources: BIS, World Bank, Payments.com, and author's calculations.

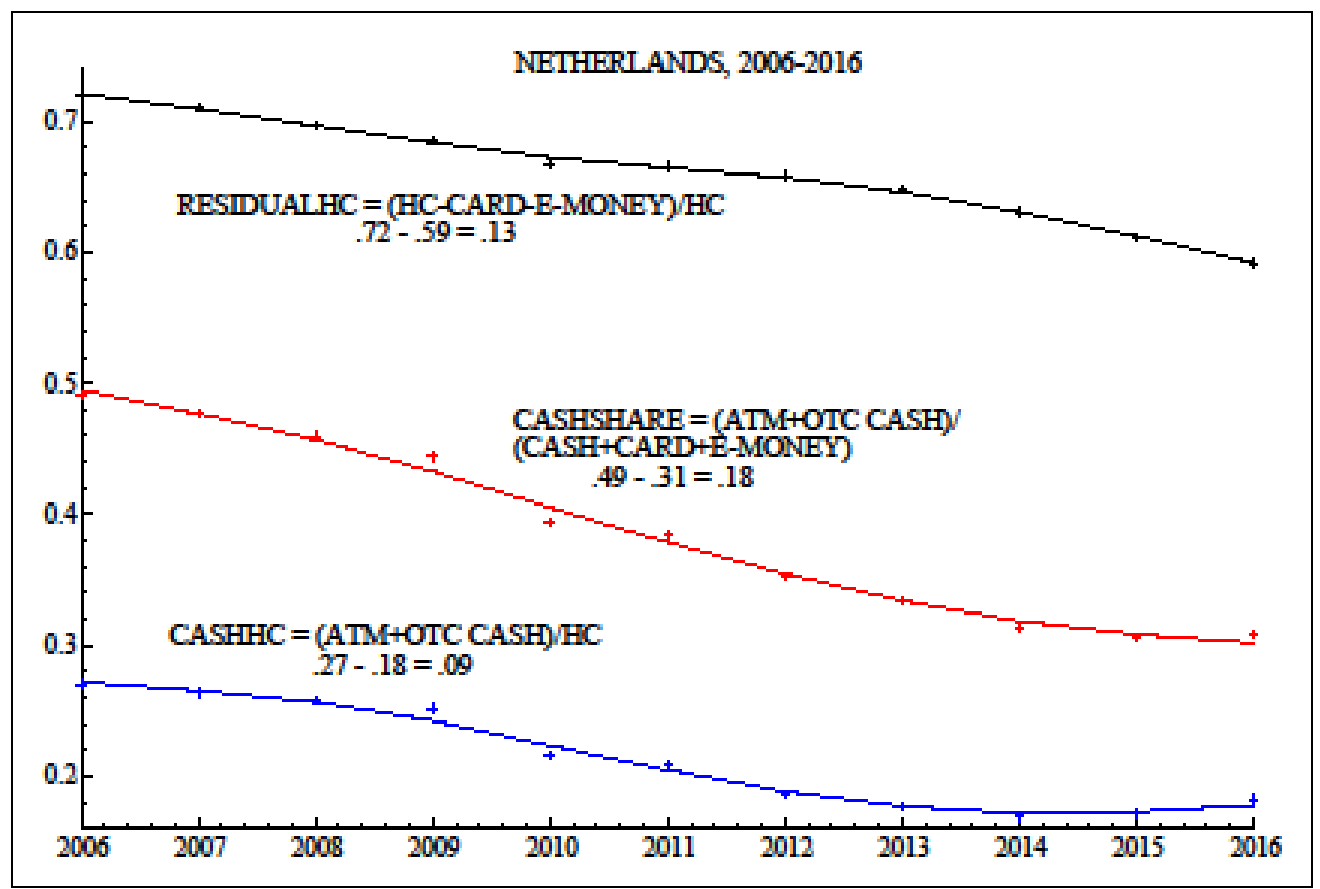

Sources: BIS, ECB, World Bank, and author's calculations. 


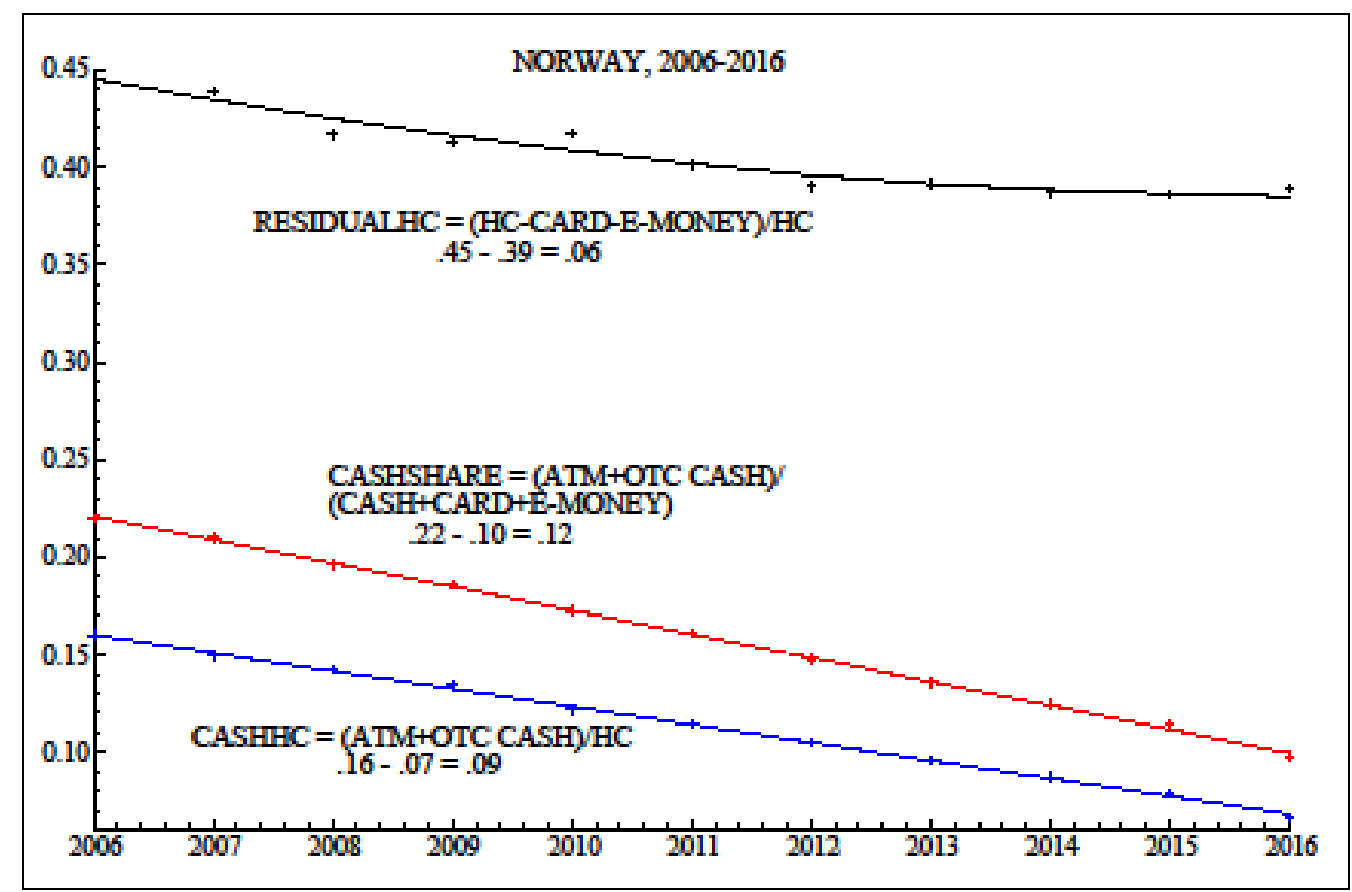

Sources: Norges Bank, World Bank, and author's calculations.

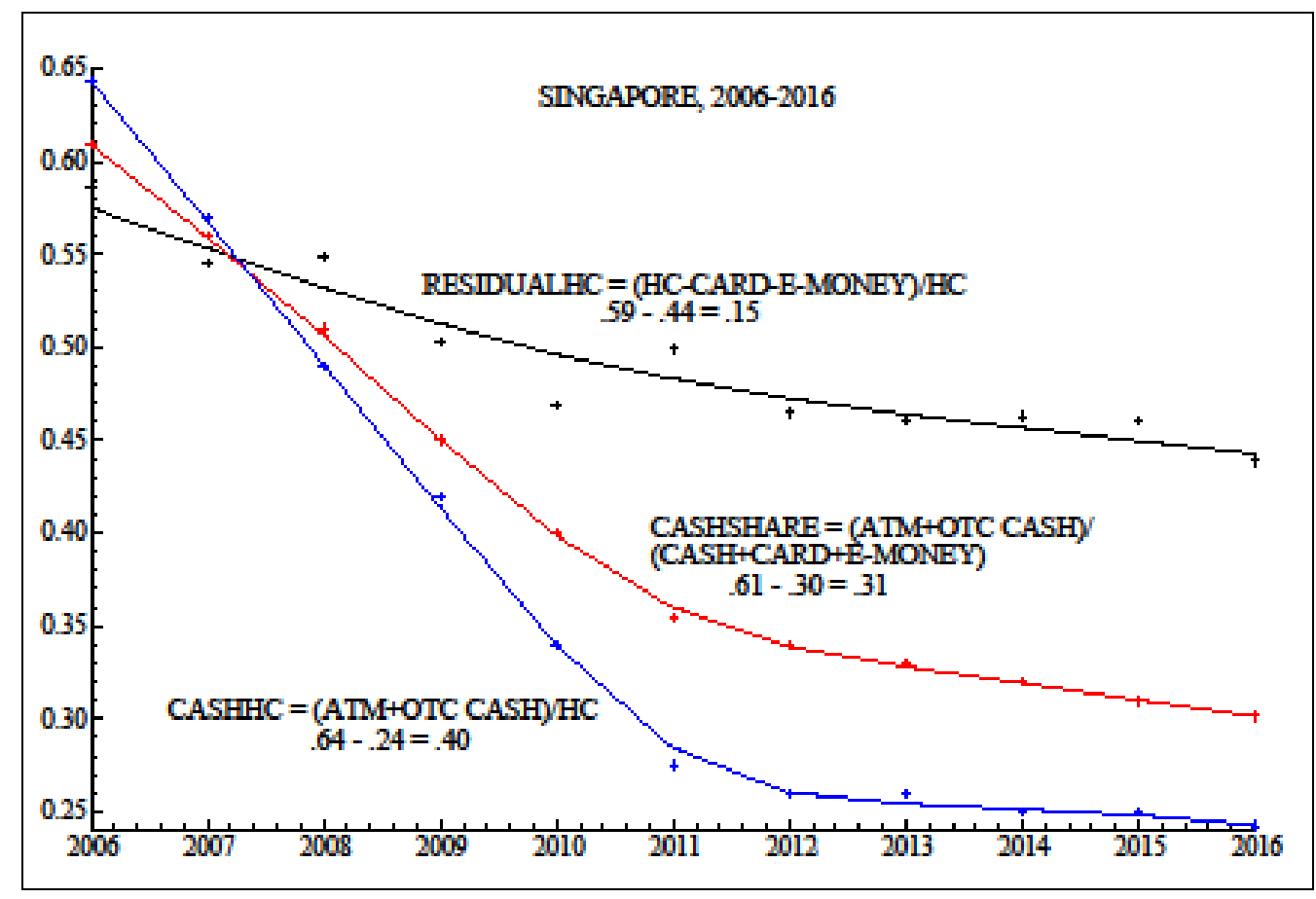

Sources: BIS, World Bank, and author's calculations. 


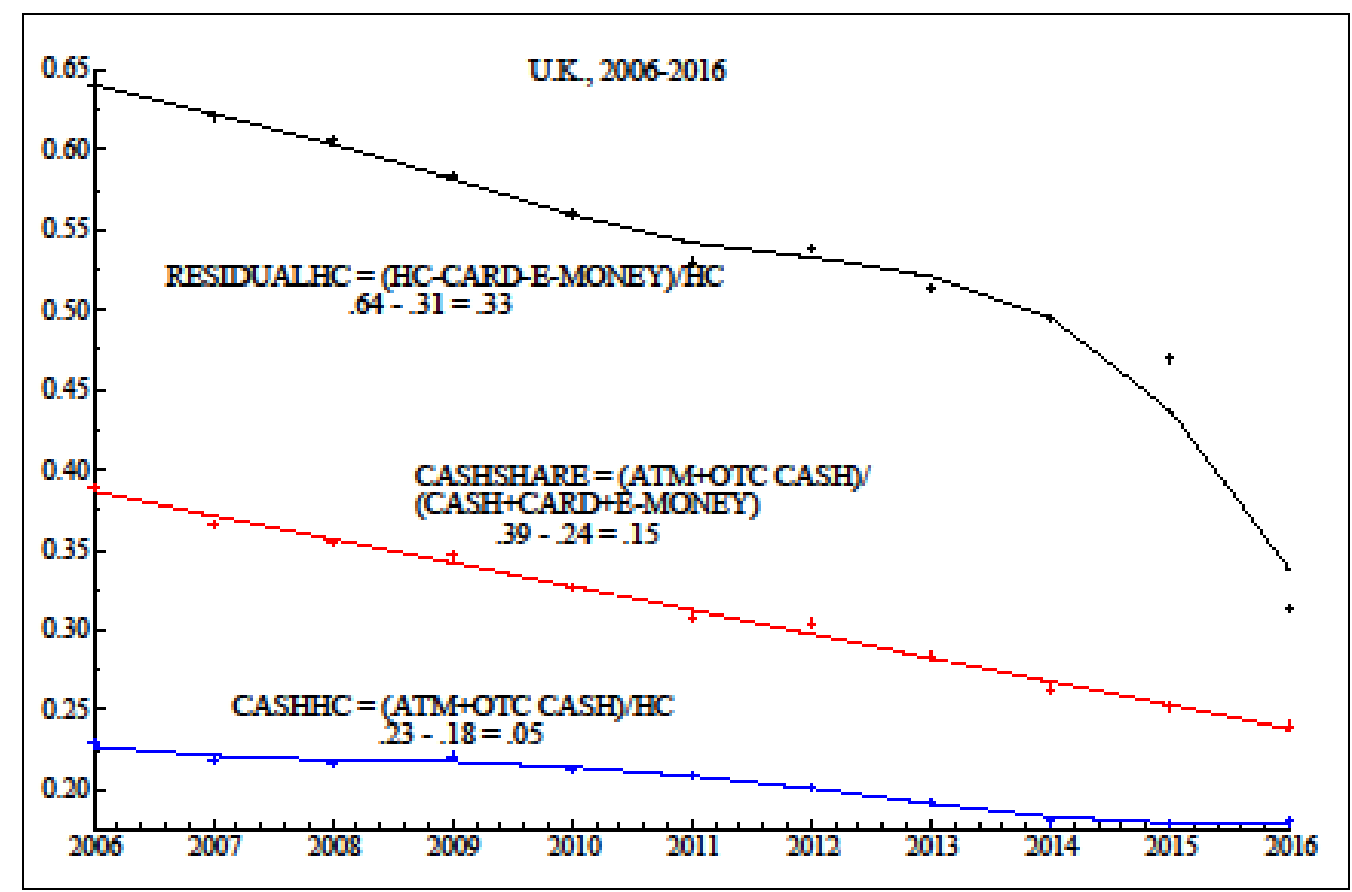

Sources: BIS, ECB, World Bank, Payments.com, and author's calculations.

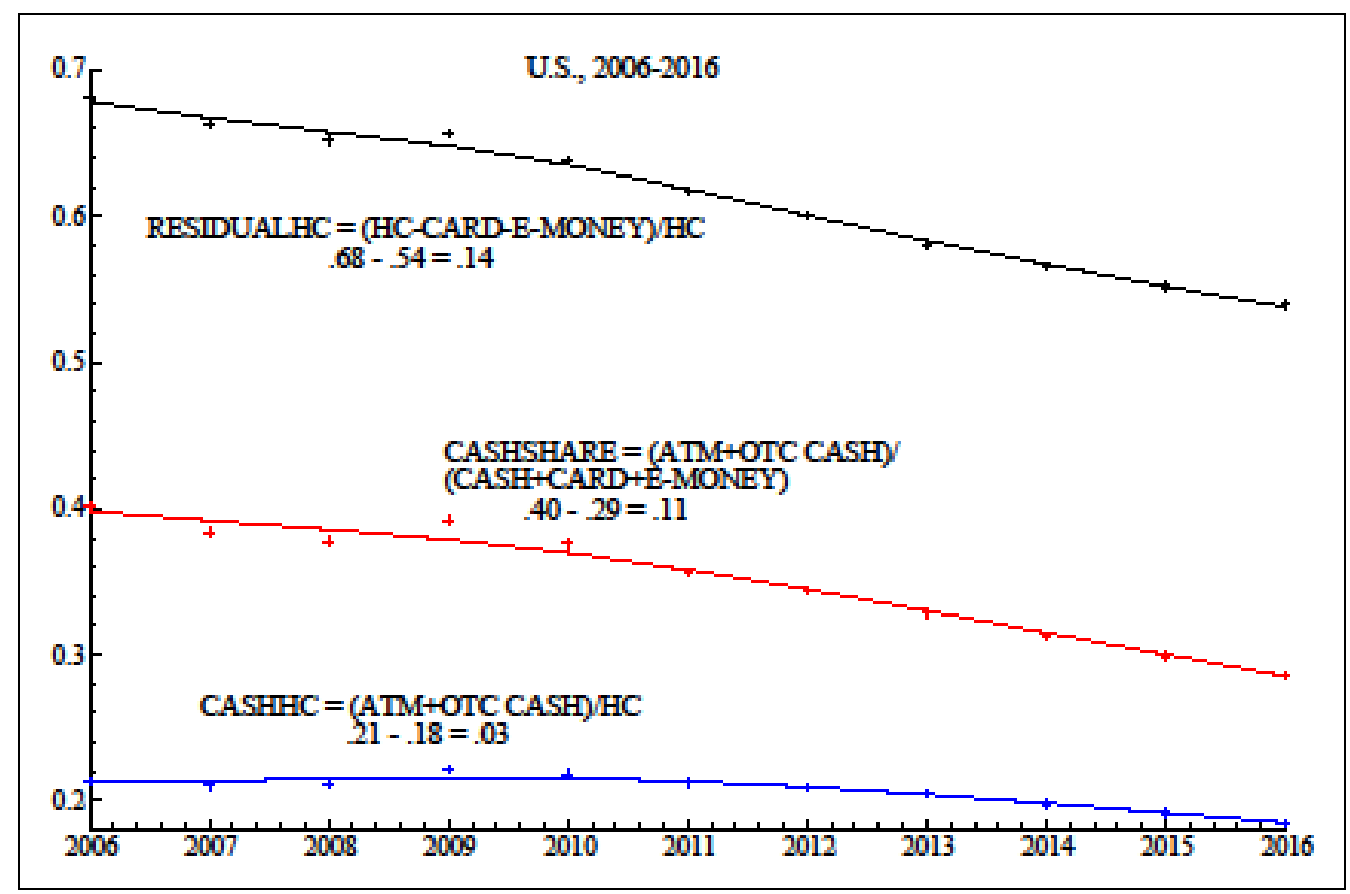

Sources: BIS, World Bank, Payments.com, and author's calculations. 